\title{
Althusser's Late Thinking About Materialism
}

and the book of events

is always open halfway through. Wislawa Szymborska, 'Love at First Sight'1

\section{Introduction}

General periodisation of Althusser's work

Considered most broadly, Althusser's engagement with Marx and Marxism took place in two stages. The first began with his entry into the French Communist Party in 1948 and ended around the mid-1970s. It was marked by attempts at a critical appropriation of certain parts of Marx's thought. The more-or-less purely theoretical - centrally philosophical - character of this work was, he wrote, both cause and result of his political isolation in the Party. 'I wished to ... to struggle against triumphant Stalinism and its disastrous effects on my party's politics. I had no choice at the time: if I had intervened publicly in the politics of the Party, which refused to publish even

${ }^{1}$ In Szymborska 1995, p. 198. The theme of contingency occurs in other poems in the same volume, e.g. 'Could Have' (pp. 65f) and 'Under One Small Star' (pp. 91f). 
my philosophical writings (on Marx), judged heretical and dangerous, I would have been, at least down to 1970, immediately expelled, marginalized and left powerless to influence the Party at all. So there remained only one way for me to intervene politically in the Party: by way of pure theory - that is, philosophy'. ${ }^{2}$ The second period, which lasted to the effective end of his intellectual life about 1986, was politically a time of public criticism of the French Communist Party and theoretically one of wide-ranging criticism of Marx and Marxism, as well as other positions (such as Lacan's), including major aspects of his own earlier ones, some of all this involving new developments in his thought.

\section{The question of materialism in Althusser's late work}

A major subject of reflection in this second phase was materialism - 'one of the most sensitive subjects [thèmes névralgiques] in philosophy', 'the hardest question of all'. ${ }^{3}$ Very roughly speaking, his work here falls into two periods. The first is marked most notably by his lecture 'The Transformation of Philosophy' (1976). During the second, from about mid-1982 to mid-1986, he produced a number of pieces which sought to delineate a certain 'unique tradition' of materialism, an 'underground current', a 'materialist tradition almost completely ignored in the history of philosophy', ${ }^{4}$ which was not present (explicitly anyway) in his earlier writings. ${ }^{5}$ This he called both the 'materialism of the encounter [matérialisme de la rencontre]' and 'aleatory materialism' (by which latter name it will be referred to from now on). ${ }^{6}$ Only

2 Althusser 1994d, p. 30. Also Althusser 1994e, pp. 185f, 196f, 221f. (On the aims and achievements of Althusser and his group during the period 1965-75, Althusser 1994 d, p. 86.) See also a passage in some private, posthumously published notes from 1977-8 (Althusser 1994f, pp. 447-9) beginning: 'Philosophy properly so-called was for me only on the horizon of political philosophy.'

3 Althusser 1994d, pp. 94, 56.

4 Althusser 1994b, p. 539f.

5 The qualification in parentheses is meant to take account of, for instance, Althusser's remark in a 1985 letter in which he speaks of 'thoughts that I have preserved and cultivated very carefully for a good thirty years, sharing them with only a very few intimates', thoughts 'on the philosophy of "the encounter", which I am jealously sitting on' (Althusser 1994d, p. 123). In a closely related passage in Althusser 1994e (p. 268), he writes: ' . . . between November 1982 and February 1983 . . . I expressed, for the first time in writing a certain number of ideas I had stored away in my mind for over twenty years...'.

${ }^{6}$ I have chosen this designation for two main reasons. Much the more important one is that there are good textual grounds. It was the title of one of his last scripts, dated 11 July 1986 (Althusser 1994c, p. 538), in Althusser 1994d it seems clearly to be 
a small part of this was publicly accessible during his lifetime, and not all of it has been published since his death. However, it seems fairly clear that, at the very least, enough of it is now in print to permit a study of its main lines. ${ }^{7}$ This will be the main task of the present paper.

\section{Scope of the paper}

This is not an easy undertaking, both because the ideas in question are in themselves quite difficult, and because they are mostly presented in a very condensed and indeed often somewhat fragmentary way. (Althusser himself speaks, in a 1985 letter, ${ }^{8}$ simply of the 'intuitions' set out in one of his main presentations ['Le courant souterrain du matérialisme de la rencontre'].) Consequently, this material will certainly become the subject of much controversy as regards both interpretation and evaluation, and the present inquiry can at best contribute to the earliest stages of this discussion. ${ }^{9}$ For

Althusser's preferred nomination (e.g. pp. 35 and, especially, 42), and it is term used the whole time by his interlocutor there (e.g. pp. 23, 34). A very subordinate one is that I cannot think of an acceptable English translation of the first, whereas 'aleatory materialism' is both a literal translation and perfectly acceptable English. (It may be worth remarking that 'aléatoire' is rendered in Althusser 1994e by 'uncertain'. This is inaccurate, for the latter belongs primarily to the epistemic context, the former to the context of fact; aleatoriness entails uncertainty but not conversely. This lapse - in an otherwise excellent version - is especially unfortunate as it in effect conceals from the reader solely of the English translation some valuable personal clues to the understanding of Althusser's late thought. See, e.g. pp. 116, 166, 227, 280, 282, 285, etc. In this last regard, see also 1994f, pp. 458f.)

7 The main very late texts which will be in question in this paper are, listed in the order (or probable order) of dates of composition: (1) Althusser 1994a; (2) Althusser 1994b; (3) Althusser 1994d; (4) Althusser 1994e; (5) Althusser 1993 (partial translation 1997); (6) 'Portrait du philosophe matérialiste' in Althusser 1994c, pp. 581-2.

8 Althusser 1994d, p. 123.

9 The history of these texts, so far as I can piece it together from editorial notes to them, seems to be essentially the following: Althusser 1994a was probably written in the summer of 1982, with an eye to its incorporation into a book which was never completed, but the main elements of which are contained in Althusser 1994b, posthumously edited from pages written in autumn 1982. The most important part of Althusser 1994d for present purposes consists of French texts (initially published in Spanish as Althusser 1988a) based on a series of interviews with Althusser by Fernanda Navarro, written up mainly by the latter using the interviews themselves, a script of the never completed book just referred to, and earlier published and unpublished texts by Althusser; the result was also worked over by Althusser himself, who contributed a brief preface. Althusser 1994d also contains some letters from Althusser (mainly to Navarro). The whole spans 1984-7. Althusser 1994e was written in early 1985. Althusser 1993/1997 consists of two chapters from the original draft of the preceding, later dropped and replaced by a summary (at pp. 215-20). 'Portrait du philosophe matérialiste was one of a group of philosophical pieces written during June-July 1986, presumably his last. 
these reasons, and also because most of this recently published material has not yet appeared in English translation, I shall both give fairly detailed references to and also quote extensively from it..$^{10}$ But the matters in question will require much thorough thinking through of the issues and, to some extent, supplementation of what is not, in the patent sense at least, in the texts themselves. I raise questions of criticism only where these are useful - or even necessary - for tackling the task of exegesis. In general, I shall be content if the paper goes some way to exhibiting, with regard to its theme, what are, in Althusser's own memorable words, the 'elementary but necessary ingredients of authentic thought - rigour, coherence, and clarity'. ${ }^{11}$

\section{Layout of the paper}

Since Althusser on occasion calls the tradition of materialism with which he is concerned 'underground' or 'subterranean', that with which it is contrasted may be dubbed 'superterranean'. Section I will be devoted to sketching it. Section II is a first attempt at an outline of the former. Section III presents some problems which arise with this. Assistance in solving these problems is sought in a perhaps prima facie unlikely place, namely, Wittgenstein's Tractatus Logico-Philosophicus, and Section IV will contain an outline of some parts of this work. Section V tackles the problems set out in Section III with the help of what is in Section IV. Section VI supplements the considerations contained in the preceding section. In Section VII, the general elucidation resumes, treating the closely connected themes of necessity as a modality and of lawfulness (in the scientific sense). Section VIII takes up Althusser's very

Althusser 1990a will also be extensively referred to at certain points; it is an earlier text, but sets out some positions present in the later ones, though not in the same amplitude. In addition, it has the immense advantage of having been publicly presented by Althusser himself and indeed published during his life-time (though in Spanish) and also the not inconsiderable one of being available in English.

Althusser 1995 contains earlier texts which, in the main, have less relevance to the subject of this paper than those listed so far. However, it will be necessary to cite some of them later on.

${ }^{10}$ [Editorial note: all translations not otherwise attributed are either by the present author or taken from a collection of Althusser's work to be published by Verso in 2005 under the title Later Writings. The text of the present essay has been modified, where necessary, to bring it into line with the translations to appear in Later Writings. In particular, it should be noted that 'gel', Suchting's translation of 'prendre' in Althusser's technical use of the term, has been changed throughout to 'take hold'. Thanks to G.M. Goshgarian for help in such matters.]

${ }_{11}$ Althusser 1994e, p. 223. 
puzzling notion of 'constant', inevitably in connection with the notion of law. Section IX discusses a number of questions clustering about the themes of the status of 'aleatory materialism' as a 'philosophy'. Finally, in Section X, I shall briefly outline some further questions which have emerged or been suggested by the preceding inquiry and which constitute part of the agenda for further work in this area.

\section{The superterranean current of materialism}

\section{General characterisation of traditional philosophy}

What is being called here the 'superterranean' current of materialism belongs, Althusser claims, to traditional philosophy. One of his characterisations of the latter is as follows (the matter will be returned to later on).

Philosophy ... appears as the science of the Whole - that is to say, of all things ... philosophy ... considers it has an irreplaceable task to accomplish. This is to speak the Truth about all human practices and ideas. Philosophy believes that ... if it did not exist, the world would be bereft of its Truth ... [and] ... for the world to exist, it is necessary for such truth to be spoken. This truth is logos, or origin, or meaning. ${ }^{12}$

Thus, from this perspective, traditional philosophy is constituted in the first place by its concern with the totality of what exists ('the Whole'), and with the truth about this totality qua totality ('the Truth') - that is, with claims of

12 Althusser 1990a, pp. 245, 246. Althusser said similar things before, e.g. 1971, p. $173 ; 1990$, pp. 80,103 , and also works belonging to the period particularly in question in this study - see e.g. Althusser 1994d, pp. 43, 50, Althusser 1994e, p. 170. In terms of the distinction made well-known by Isaiah Berlin, it is the truth of the hedgehog rather than the fox: 'The fox knows many things. The hedgehog only one./ One big one.' ('Archilochos' as translated by B.H. Fowler in Fowler 1992, p. 62, \#201.) It may be remarked that Althusser's characterisation of the nature of philosophy as traditionally understood is in line with ones available in various 'standard' sources. For example, Dilthey writes that 'religion, poetry and unsophisticated [urwüchsige] metaphysics express the significance and meaning [Bedeutung und Sinn] of the whole.... The appearance of a world-view ... . with a claim to universal validity marks the beginning of metaphysics ... which promises to solve the riddle of life in a methodical way' (Dilthey 1960, pp. 82, 94,96). Jaspers writes: 'What one calls philosophy is preoccupation with the whole. ... The metaphysical world-view ... is concerned with the whole (or totality) and the absolute (or the unconditioned, ultimate). The structure of the human spirit is such that (he absolute is, as it were, a location [ein Ort] for man, where he must, unavoidably, put something, be it practically, in his life, without knowing it in its own character, or in a thinking way for his consciousness also' (Jaspers 1994, 1, p. 184f). 
unrestricted generality about what exists - a truth which is about the origin and meaning/telos of the totality qua totality.

\section{The two basic tendencies in traditional philosophy}

Philosophy as thus conceived exhibits two fundamental 'lines', namely, idealism and materialism. These are only fundamental tendencies: each line, each specific system so labelled, contains elements of the other, ${ }^{13}$ or what Althusser calls a 'mutual encroachment [empiétement]' of idealism and materialism. ${ }^{14}$ This is because what constitutes a philosophy is its position in what Kant called, with reference to metaphysics, a 'battlefield [Kampfplatz]', and in this struggle each seeks to invest the enemy on his own territory. ${ }^{15}$

Idealism is explicitly concerned with Origin and End. ${ }^{16}$ But 'every ... materialism of the rationalist tradition ... including that commonly attributed to Marx, Engels and Lenin . . . is a materialism of necessity and teleology, i.e., a disguised form of idealism' ${ }^{17}$ This traditional materialism regards order as immanent in disorder (which is teleological), and contingency as an exception with respect to a fundamental necessity. ${ }^{18}$ (There are also examples of the contrary situation, that is, of elements of materialism in idealism..$^{19}$ )

${ }_{13}$ Althusser 1994d, pp. 52, 56-8, 95-7, 103. Also, at many other places, e.g. Althusser 1976 , pp. 61 n. 20, 144f. Althusser refers to Macherey 1976 and Raymond 1973. The two-lines view in general is due to Engels (1970, Chapter 2, pp. 345ff), though he considers them in unconditional terms. The nuance of tendencies is probably due to remarks on Kant in Lenin 1962, p. 198.

14 Althusser 1994d, pp. 98, 103f.

15 Althusser 1994d, pp. 35, 51f, 53f, 55, 102-5, and many other places, e.g. Althusser 1976, p. 166; Althusser 1990a, p. 255; Althusser 1997, pp. 10f. (For Kant's reference see Critique of Pure Reason, A viii.)

${ }_{16}$ Althusser 1994d, pp. 58, 97; 1994b, 542f, 561f.

17 Althusser 1994 d, p. 42 - also pp. 95ff. There is a parallel passage in Althusser 1994b, p. 540. (This is how Althusser puts it, but a stricter formulation would be, arguably, that traditional materialism contains elements of idealism rather than being a form of it.)

18 That is, presumably, the End - viz. order - is implicit in the Origin from which it develops of necessity. Cf. Althusser 1994b, pp. 540, 542, 565; Althusser 1994d, p. 42.

${ }_{19}$ For the case of Hegel see 1971, pp. 118f, 182-4; Althusser 1976, pp. 178, 180f; Althusser 1997, p. 4; Althusser 1994d, p. 112f. Cf. Lenin on Kant referred to in note 13 , above. 


\title{
II. The 'underground', 'unique' current of 'aleatory' materialism: a preliminary outline
}

\section{Origins and representatives of aleatory materialism}

Whether or not Althusser finds the historical origin of aleatory materialism in Epicurus, it is by reference to him (rather than, say, to the earlier Democritus ${ }^{20}$ ) that he presents its basic principles, and by reference to which he identifies it or elements of it in a wide variety of later thinkers: in the first place Machiavelli, Spinoza and Marx. ${ }^{21}$ The following sets out a preliminary view of aleatory materialism, with primary reference, as in Althusser himself, to Epicurus. This will turn out to be very incomplete and so in need of extensive supplementation, but it will afford an initial orientation.

\section{Atoms and the void}

Althusser writes:

\begin{abstract}
Epicurus says that before the formation of the world an infinity of atoms were falling parallel to each other in the void. They are still falling. This implies ... that ... before the formation of the world, there was no Meaning, neither Cause nor End nor Reason nor Unreason [Déraison]. ${ }^{22}$
\end{abstract}

${ }^{20}$ Althusser seems to be inconsistent about the character of Democritus's materialism. It is often referred to in the same breath with that of Epicurus (e.g. Althusser 1994d, pp. 35, 40, 42, 47; Althusser 1993, p. 102f), and, indeed, the first section of Althusser 1994d is headed 'A Philosophy for Marxism: The Line of Democritus' (Cf. Lenin 1962, p. 130, who writes of 'the struggle between materialism and idealism, the struggle between the tendencies or lines of Plato and Democritus in philosophy'.) But in e.g. Althusser 1994 b, p. 565, Democritus is cited as a form of traditional materialism: 'Epicurus ... never adhered to the "mechanical" materialism of Democritus, this materialism being only a resurgence, within a possible philosophy of the encounter, of the dominant idealism of Order as immanent in Disorder.' Althusser 1994b, p. 563 appears to be ambiguous.

${ }^{21}$ On Machiavelli: 1994b, pp. 543-8, Althusser 1994d, p. 48, Althusser 1993, pp. 99-111 and Althusser 1997, pp. 3, 13-16, Althusser 1994e, pp. 220, 231, 241f (also Althusser 1988b), and Althusser 1999. On Spinoza: Althusser 1994b, pp. 548-52, Althusser 1994d, pp. 33, 59f, Althusser 1997, pp. 4-13, 18-19, Althusser 1994e, pp. 216-19, 241 and cf. Althusser 1976 esp. pp. 132ff. Others are Hobbes: Althusser 1994b, pp. 552-6; Rousseau 1994b, pp. 556-61, Althusser 1994e, pp. 219f. Pascal: Althusser 1994b, p. 547, Althusser 1994d, pp. 52f, 156, Althusser 1993, p. 102 and Althusser 1997, pp. 3f, 10; Heidegger: Althusser 1994b, pp. 542f, 547, 562, 563f, Althusser 1994d, pp. 41, 116, 123; Wittgenstein: Althusser 1994b, p. 563, Althusser 1994d, p. 46; Derrida: Althusser 1994b, pp. 551, 561, 562, 563, Althusser 1994d, pp. 42, 43, 47, Althusser 1993, pp. 102, 103, 105, Althusser 1994e, pp. 178, 182. Even Kant and Hegel are mentioned in this connection (Althusser 1997, pp. 4f, Althusser 1993, p. 102 - see also note 19 above), also Nietzsche, Althusser 1994d, pp. 98, 108f.

${ }^{22}$ Althusser 1994b, p. 541. 
Thus, 'before the formation of the world'23 there exist two basic items: (i) atoms, and (ii) a void. Furthermore, regarding (i), it is said (iii) that there is an infinity of them, (iv) that they fall through (ii), and (v) that they so fall in parallel lines. This is all that exists. Hence no Meaning, nor Cause nor End nor Reason/Unreason.

\section{'Swerve', 'encounter', world-formation}

Supervenient upon this situation there occurs a clinamen,

an infinitesimal swerve [déviation]; 'no-one knows where, or when, or how' it takes place, or what causes an atom to 'swerve' from its vertical fall in the void, and, breaking the parallelism in an almost negligible way at one point [sur un point], induce an encounter [rencontre] with the atom next to it, and, from encounter to encounter, a pile-up [carambolage] and the birth of a world - that is, of the aggregation of atoms induced, in a chain reaction, by the initial swerve and encounter. [Thus] ... the origin of every world, and therefore of all reality and all meaning, is due to a swerve ... ${ }^{24}$

More precisely:

In order for the swerve to give rise to an encounter out of which a world is born, that encounter ... must be ... a lasting encounter, which then becomes the basis for all reality, all necessity, all Meaning and all reason. But the encounter can also not last, and then there is no world.... The world may be called the accomplished fact ... this accomplishment of the fact is just a pure effect of contingency, since it depends on the aleatory encounter

${ }^{23}$ Althusser sometimes speaks, as here, of the formation of 'the' world and sometimes of ' $a$ ' world. I cannot see that anything hangs on this distinction. I suggest that ' $a$ ' simply emphasises the position - set out in the rest of the passage - that there are many possible worlds, whilst 'the' makes the points which are made by reference to one (otherwise uncharacterised) of them which happens to be realised. So I shall use the two articles - as Althusser seems to do - interchangeably.

${ }^{24}$ Althusser 1994b, p. 541. I render 'déviation' as 'swerve' rather than, as would be verbally closer to the original, 'deviation', because Lucretius's Latin 'clinamen' (Lucretius 1992, 2.292 - cf. his use, in this passage of the verbs inclinare, declinare) is standardly translated into English, in this context, by 'swerve' (or 'swerving'), as is the Greek equivalent [parenglisis] in the context of the philosophy of Epicurus. (The idea does not occur in the latter's extant writings but is ascribed to him, with complete certainty, on the basis of ancient doxographical reports.) It may be added that, on at least one occasion (Althusser 1994d, p. 42), Althusser speaks of the 'déviation' as being 'produced' by the clinamen. But this must be a slip, since, as the passage to which this is a note correctly puts it, the two are identical. 
of the atoms due to the swerve of the clinamen. ... [O]nce the fact has been accomplished, [there] is established the reign of Reason, Meaning, Necessity and End. ${ }^{25}$

Thus, to continue the above listing of basic points, there may occur (vi) a 'swerve' - in the previously parallel vertical motion of an atom, producing (vii) an 'encounter' between it and a neighbouring atom. As a consequence, a 'world' may arise. Whether it does depends on (viii) whether the encounter 'lasts' (The passages cited are not quite clear about what exactly must 'last', but presumably it is the result of the 'chain-reaction' of encounters.) At any rate, (ix) both the original encounter and any subsequent ones are purely contingent, aleatory. This is presumably what Althusser means when he writes later of 'the miracle of the clinamen [le miracle $d u$ clinamen]':26 a 'miracle', it may be assumed, insofar as it is something which has no (natural) explanation. ${ }^{27}$ Consequently, the world produced is similarly purely contingent, aleatory. However, ( $\mathrm{x}$ ) becomes the basis of Meaning (etc.) which was not there before. Thus the world does not have its origin in anything which could confer meaning on it; rather, the world confers meaning on itself, as it were.

In sum ...

At one place, Althusser formulates aleatory materialism in lapidary form as 'a philosophy simply of result'. ${ }^{28}$ Again, several times he uses a striking figure:

the idealist philosopher is a man who, when he catches a train, knows from the outset the station he will be leaving from and the one he will be going to; he knows the beginning [origine] and end of his route, just as he knows the origin and destiny of man, history and the world. The materialist philosopher, in contrast, is a man who always catches 'a moving train', like

5 Althusser 1994b, pp. 541, 542.

${ }^{26}$ Althusser 1994b, p. 564.

${ }_{27}$ Althusser warns elsewhere (Althusser 1994d, p. 42) against interpreting the clinamen and the deviation it produces in the direction of an 'idealism of freedom': 'the existence of human freedom in the world of necessity itself'. However, the preservation of freedom as against the Democritean doctrine of thoroughgoing necessity was at least one of Epicurus's own basic motives in introducing the doctrine of the swerve (see e.g. his Letter to Menoeceus, 133-4), and this consideration certainly counted heavily with Lucretius (1992, 2, pp. 251-93). Other ancient writers also read Epicureanism this way (e.g. Cicero, De Fato, x, 22-3). It was one of the features of Epicurus's philosophy of nature which recommended it over that of Democritus to Marx in his doctoral dissertation (Marx 1968, especially Part II, Chapter 1).

28 Althusser 1993, p. 105. 
the heroes of American Westerns. A train passes by in front of him: he can let it pass [passer] and nothing will happen [se passe] between him and the train; but he can also catch it while it is moving. This philosopher knows neither Origin nor first Principle nor destination. He boards the moving train and settles into an available seat or strolls through the cars, chatting with the travellers. He witnesses, without having been able to predict it, everything that occurs in an unforeseen, aleatory way, gathering an infinite amount of information and making an infinite number of observations, as much of the train itself as of the passengers and the countryside which, through the window, he sees rolling by. ${ }^{29}$

\section{Some problems for the further exegesis of 'aleatory materialism'}

\section{A problem about the ontological status of 'atoms'}

What has been said in the passage from the major exposition already cited above (in the subsection "'Swerve", "encounter", "world-formation'") 'implies', Althusser continues, that

before the formation of the world, there was nothing, and also that all the elements of the world existed from all eternity, before any world ever was.... [T] he encounter creates nothing of the reality of the world, which is nothing but agglomerated atoms, but... it endows the atoms themselves with their reality, which, without swerve and encounter, would be nothing but abstract elements lacking substantiality [consistance] and existence. ... The encounter in no way creates the reality of the world, which is only agglomerated atoms, but ... it confers their reality upon the atoms themselves, which without swerve and encounter, would be only abstract elements, with neither consistence [consistance] nor existence. ... [T] he atoms' very existence is due to nothing but the swerve and the encounter prior to which they led only a ghostly [fantomatique] existence. . . . Before the accomplishment of the fact, before the world, there is only the non-accomplishment of the fact, the non-world that is merely the unreal existence of the atoms. ${ }^{30}$

${ }_{29}$ Althusser 1994d, 64f. See also the use of the image of the traveller in Althusser 1994e, pp. 187, 217, in Althusser 1997, p. 13, and in most detail in 'Portrait du philosophe matérialiste' (Althusser 1994c, p. 581f), what would seem to be his last philosophical writing. (Cf. Pirandello's story, 'A Day Goes By', available in Pirandello 1987.)

${ }^{30}$ Althusser 1994b, pp. 541f, cf. p. 546 and Althusser 1994d, pp. 40 f. 
This seems to threaten the intelligibility of the picture just sketched. How can it be the case both that there is 'nothing' before the formation of a world and also that the elements of the latter, the atoms, exist eternally? This problem is hardly cleared up by the assertion that, before the formation of a world, these elements exist in a merely 'abstract', 'ghostly', 'unreal' way. What could be meant by this?

A similar exegetical problem arises in a slightly later passage, according to which once an encounter has resulted in a durable outcome

... the atoms enter the realm of Being that they inaugurate: they constitute beings, assignable, distinct, localisable beings endowed with such-and-such a property (depending on the time and place); in short, there emerges in them a structure of Being or of the world that assigns each of its elements its place, meaning, and role, or, better, establishes them as 'elements of ...' in such a way that the atoms, far from being the origin of the world, are merely the secondary consequence [retombée] of its assignment and advent [assignement]. ${ }^{31}$

This, in effect, repeats the exegetical puzzle set out to start with: whereas, to start with, it seemed as though atoms are 'the origin of the world', or, at least, the existential presupposition of the encounters which gives rise to a 'world', it seems now to be said, in effect, that the converse is the case.

\section{Problems about the 'swerve'}

If what endows the atoms with reality is encounters (whatever that may mean) and if what produces encounters are swerves, then it would seem to follow that the latter are (to borrow a phrase from Aristotle) 'prior by nature' to the parallel, rectilinear motion which up to this point seemed to be ascribed to atoms in their primordial state. This is in fact affirmed where Althusser speaks of 'the primacy of the swerve over the rectilinearity [rectitude] of the straight [droit] trajectory'. ${ }^{32}$ But what can 'swerve' mean (in this context anyway) if not deviation from a rectilinear path?

Confusion is worse confounded by the following passage:

In the 'nothing $[$ rien]' of the swerve there occurs an encounter between one atom and another, and this event [événement] becomes advent [avènement] on

\footnotetext{
${ }^{31}$ Althusser 1994b, p. 565.

32 Althusser 1994b, p. 562.
} 
condition of the parallelism of the atoms, for it is this parallelism which, violated on just one occasion [une unique fois], induces [provoque] the gigantic pile-up and collision-interlocking [accrochage] of an infinite number of atoms, from which a world is born (one world or another: hence the plurality of possible worlds, and the fact that the concept of possibility can be rooted in the concept of original disorder). ${ }^{33}$

Why is the swerve called 'nothing', or, more precisely, "'nothing"'? What is to be understood by 'event' and 'advent'? How can the 'parallelism' (of motions) be said to be 'violated' if the swerve is indeed ontologically primary?

\section{A problem about the determinants of a 'world'}

The previously cited passage continues immediately:

Whence the form of order and the form of beings whose birth is induced [provoquées à naitre] by this pile-up, determined as they are by the structure of the encounter; whence, once the encounter has been effected (but not before), the primacy of the structure over its elements ... ${ }^{34}$

Does the final remark imply that before the encounter there was a structure, but that it did not have a primacy over the elements? But what could this structure be but the parallel vertical fall of the atoms in the void? And is it implied that, at this stage, the elements have primacy over the structure?

... whence, finally, what one must call an affinity and complementariness [complétude] of the elements that come into play in the encounter, their 'readiness to collide-interlock [accrochabilité]', in order that this encounter 'take hold [prenne]', i.e., 'take form [prenne forme]', finally give birth to Forms, and new Forms - as water 'takes hold' when ice is there waiting for it, or milk does when it curdles, or mayonnaise when it emulsifies. Hence the primacy of 'nothing' over all 'form', and of aleatory materialism over all formalism. In other words, not just anything can [n'importe quoi] produce just anything, but only elements destined [voués] to encounter each other and, by virtue of their affinity, to 'take hold' one on [sur] the other ... the atoms are ... 'hooked', that is, susceptible of [propres à] interlocking one after the other, from all eternity, for good, for ever. ${ }^{35}$

33 Althusser 1994b, p. 564.

${ }^{34}$ Ibid.

${ }^{35}$ Althusser 1994b, pp. 564f. The translation into English of 'prendre' /'prise' as 
This passage seems to affirm that atoms have properties prior to their encounters with one another and that these properties delimit or constrain the possible outcomes of encounters. But this appears to be inconsistent with the previous assertion that atoms are, prior to their encounters, merely 'abstract' (etc.) (whatever that may mean). We are used to the idea that the 'abstract entities' of pure mathematics have definite properties, but it is indeed much less clear how an atom could intelligibly said to have them without being existentially determinate.

However, a little further on, Althusser seems to restate the idea that the atoms, considered in themselves, as it were, have no determinate properties:

... nothing in the elements of the encounter prefigures, before the actual encounter, the contours and determinations of the being that will emerge from it.... [N]o determination of the being which issues from the 'takinghold' of the encounter is prefigured, even in filigree [en pointillé], in the being of the elements that converge in the encounter. Quite the contrary: no determination of these elements can be assigned except by working backwards [dans le retour en arrière] from the result to its becoming, in its retroaction. ${ }^{36}$

Finally, shortly after this, Althusser writes, apropos Hobbes:

No doubt man in the state of pure nature, although he has a body and, so to speak, no soul, bears within himself a transcendent capacity for all that he is and all that will happen to him - perfectibility - which is, as it were, the abstraction and transcendental condition of possibility for all anticipation of all development; and also a faculty that is perhaps more important, pity. ... But all that, which is posed from the beginning of the state of 'pure' nature, is not active there, has no existence or effect, is only expectation of the future that awaits man. ${ }^{37}$

\footnotetext{
Althusser uses them here and clinamen poses a problem which I cannot see how to solve in any very satisfactory way. It arises from the fact that no single set of cognate English words is appropriate for all the contexts in which Althusser uses the original ones, and the fact that, since they have a sort of technical use in his lexis, they would seem to require a univocal English rendering. Althusser 1994e, p. 227 has 'gel', which is excellent in some contexts but unacceptable in others; e.g. one cannot properly say that water 'gels' when it turns to ice. 'Set' and 'take' (and cognates) each have similar advantages and disadvantages. [Here, preference has gone to 'take hold', perhaps the least unsatisfactory option (Suchting's choice was 'gel').]

${ }^{36}$ Althusser 1994b, p. 566.

${ }^{37}$ Althusser 1994b, p. 558.
} 
What is - indeed can be - meant here by a 'transcendent capacity', 'transcendental condition' for what is to happen in the future, one which - presumably qua 'transcendent'/'transcendental' (whatever this means) - 'has no existence'?

\section{Materials for a solution to these problems: the ontology of Wittgenstein's Tractatus}

\section{The materials}

What is to be made of these exegetical problems? I suggest that we have at least two clues to solutions.

One is afforded by Althusser's passing reference ${ }^{38}$ to the proposition which opens Wittgenstein's Tractatus Logico-Philosophicus: 'The world is all that is the case [was der Fall ist]'. The point of Althusser's citation lies in the word 'case' - in the original, Fall, cognate with fallen, to fall, this being tied up with the 'fall' of the atoms, and with 'case' from the Latin casus, 'chance' cognate with caedere, to fall. But this is not the significant point for present purposes, which is rather that it directs attention to the Tractatus as such. More specifically, I suggest that what may be called the ontology of the Tractatus presented in the paragraphs which follow the opening statement just cited, gives us, at a minimum, decisive help in solving the exegetical problems in question.

The other clue is an incidental remark by Althusser himself in a much earlier writing that 'in philosophy you can only think through metaphor' ${ }^{39}$ However, this second clue will be of more use later on. The immediate task is, then, to delineate the ontology of the Tractatus, just to the extent necessary for present purposes.

\footnotetext{
38 Althusser 1994b, p. 563 - also Althusser 1994d, p. 46 and Althusser 1997, p. 8.

39 Althusser 1976, p. 140, and similarly p. 107. It may be worth noting that this is very much in the spirit of Wittgenstein's later work where philosophical doctrines are seen as dependent upon certain 'pictures [Bilder]' embodied in language and dominating us through it (e.g. Philosophical Investigations, Pt. 1, sec. 115), pictures which are to be combated by other pictures (e.g. the picture of meanings as determined by inner images criticised with the help of languages seen in terms of the metaphor of games).
} 


\section{Elements of the ontology of Wittgenstein's 'Tractatus'}

The following two statements, from the first main section of the work, encapsulate what may be not too inadequately called the ontology set out in it, at least insofar as it is relevant to the present context. (Numbered - most often decimalised - references are all to the Tractatus. ${ }^{40}$

(A) 'The world is the totality of facts [Tatsachen], not of things [Dinge].' (1.1)

(B) 'Each one [sc. fact] can be the case or not the case and all the rest remain the same.' (1.21)

\section{The primacy of 'facts' over 'things'}

(A) presupposes a distinction between 'facts' and 'things'. What, more precisely, is meant by these terms?

(1) 'Fact' '. . a a fact is the existence [das Bestehen] of states of affairs [Sachverhalten].' (2 - cf. 2.04)

There is disagreement among commentators as to whether 'fact' and 'state of affairs' are synonymous, or whether the latter designates a certain sort of possibility, what may be called the class of 'possible facts', a 'fact' tout court being a state of affairs which is the referent of a true statement. It is not important for present purposes to go into this exegetical question. ${ }^{41}$ It must suffice to say that it is the second view which will be adopted here, if only to have a terminologically convenient way of referring to 'possible facts'. The main immediate issue is: what is meant by 'state of affairs'?

A state of affairs is a combination [Verbindung] of objects [Gegenstände] (affairs [Sachen] things). (2.01)

So, the initial expression 'things' is fairly clearly synonymous with 'objects' or 'affairs'. They may thus be used interchangeably, and what is meant by 'thing' may be elucidated by what is said about 'object' and 'affair'.

(2) 'Thing' ('Object', 'Affair') (a) 'It is essential to a thing that it can be a constituent [Bestandteil] of a state of affairs.' (2.011)

40 There are two published English translations of the Tractatus, by C.K. Ogden and F.P. Ramsey (1922) and by D.F. Pears and B.F. McGuiness (1961) - I have consulted both but followed neither consistently.

${ }^{41}$ Black 1964 discusses the issue in detail at pp. $39 \mathrm{ff}$ and comes to the conclusion that, on balance, they are at least usually synonyms. 
That is, a thing is a possible constituent of a state of affairs.

(b) '... there is no object that we can think outside its combination with others.' (2.0121)

That is: reference to a thing is intelligible only as a constituent of a state of affairs (here: a possible fact).

A thing is independent insofar as it can occur in all possible situations [Sachlagen], but this form of independence is a form of connection with a state of affairs, a form of dependence. (2.0122)

That is: a thing is independent insofar as it need not occur in any state of affairs but it is dependent insofar as it must be possible for it so to occur.

That things contain the possibility of all their combinations (cf. 2.014) and that they are only thinkable in combinations are two sides of the same coin.

(c) 'Objects are simple.' (2.02) 'Every statement about complexes can be broken-up into a statement about their constituents and into the propositions that describe the complexes completely'. (2.0201)

That is, a thing is what may be called an 'atom'. Such 'atoms' may combine into 'molecules'. However, what is true of the latter is wholly reducible to what is true about the former.

(d) ' ... if a thing can occur in a state of affairs, the possibility of the state of affairs must be already written into [präjudiziert] the thing'. (2.012) What is thus 'written into' a thing is its 'internal' versus 'external' properties (2.01231). 'A property is internal if is unthinkable that its object should not possess it'. (4.123) Thus it is objects' internal properties which determine the specific possibilities of its occurrence in states of affairs, its 'logical space' (1.13).

'The possibility of its occurring in states of affairs is the form of an object.' (2.0141) Thus the logical form of an object is the totality of its 'degrees of freedom', as it were, to combine with other objects 'an imaginary [gedachte] world, however different it may be from the real one, must have something [Etwas] - a form - in common with it'. (2.022) 'This unalterable [feste] form consists precisely in objects'. (2.023)

'Form' is connected with 'structure':

'In a state of affairs objects relate to one another [verhalten sich ... zueinander] in a definite way'. (2.031) 'The way in which objects hang together 
[zusammenhangen] is the structure of the state of affairs'. (2.032) 'The form is the possibility of the structure'. (2.033) 'The structure of a fact consists in [besteht aus] the structures of states of affairs'. (2.034)

(e) 'Objects are what is unalterable, what is stable' [das Bestehende]; their configuration is what is changing, what is unstable [Unbeständige]'. (2.0271)

'The configuration of objects forms [bildet] the state of affairs'. (2.0272)

Thus, things are, in a way, like the co-ordinates of positions in a mathematical space, in one sense independent of one another insofar as they are specific, but, in another, dependent insofar as they are positions in 'a' space. A state of affairs is a certain combination of those positions (into, for example, a square or a circle). Facts are states of affairs realised by material points which may, on occasion, occupy the relevant positions in a real space represented by the mathematical space.

(f) In a passage cited above it is said that objects/things 'hang together'. The significance of the use of this particular verb emerges from another passage. 'In the state of affairs objects fit into one another [hängen ... ineinander] like the links of a chain.' (2.03) So it is etymologically appropriate to describe a state of affairs as a 'concatenation' of objects. The central point of the remark is to deny that the objects are linked to one another by something else, which idea would, of course, lead to an infinite regress of linkages. The links are linked just by virtue of what they individually are and their position with respect to one another. ${ }^{42}$

In sum, with regard to (A): What actually exists is the totality of 'facts', that is, of certain combinations of 'things'. What facts are possible (the class of 'state of affairs') is determined by the internal properties of 'things', that is, what constitutes them as specific sorts of 'things'. But 'things' are not 'constituents' of states of affairs and hence of facts, in the sense of actually existing prior to what they are 'constituents' of, for they are always already such constituents. To borrow a term from mediaeval philosophy, 'things' may be described as 'virtual'.

${ }^{42}$ Were Wittgenstein given to historical allusions, one might think that there is a polemical one here to the mediaeval notion of vinculum substantiale, doubtless best known from Leibniz's use of it (see especially his correspondence with des Bosses). 


\section{The reciprocal independence of facts}

We turn now to (B). On the one hand, facts qua states of affairs are interdependent in the sense that the latter are subject to the constraint of 'logical space' and: 'In logic nothing is accidental' (2.012). However, on the other hand, what states of affairs are realised as facts does not depend on logic and '... outside logic everything is accident [Zufall]' (6.3). 'Whatever we can describe at all could be other than it is. There is no a priori order of things' (5.634). 'What can be described can also happen' (6.362). 'States of affairs are independent of one another. From the existence or non-existence [Bestehen oder Nichtbestehen] of a state of affairs it is impossible to infer the existence or non-existence of another' (2.061-2 and cf. 5.135). There is no 'causal nexus' (5.136, 5.1361 cf. 6.37). (Note that 'nexus' is derived from 'nectere', to bind, fasten together, and cf. the preceding remark about how objects are combined in states of affairs like links in a chain, that is, without mediation.) To borrow Black's admirable image: ${ }^{43}$ the world is a 'mosaic' of facts.

\section{The primacy of facts again}

Thus, to return to the beginning, what is being denied in affirming that the world is a totality of facts and not of things is that the world is an entity which can be named (for example, 'atoms and the void', 'God or nature', 'Absolute Spirit') rather than the common object of a set of true statements / propositions. Facts cannot be named/designated, only stated/asserted. They are, qua facts, that is, existent, irreducible to things/objects, though statements about them can be analysed into them. ${ }^{44}$

The materials contained in this section may now be used to propose a solution to the exegetical problems outlined in Section III.

43 Black 1964, pp. 3, 28, 37.

${ }_{44}$ This view is uncommon in the history of philosophy. C.S. Peirce is one of the few who held it. 'Reality belongs primarily to facts, and attaches to things only as elements of facts.' (Collected Papers, 8: p. 87, cit. Black 1964, p. 30). John Anderson, whose work is practically unknown outside Australia (and little known there nowadays), was another. 


\section{Proposed solutions to the earlier exegetical problems}

\section{The problem of the ontological status of 'atoms'}

This was (see Section III above) the problem of reconciling two positions; (i) what are ontologically and temporally primary are atoms (falling vertically and in parallel through the void), atoms which sometimes 'swerve' in aleatory fashion and are consequently involved in 'encounters' which, if lasting, form 'worlds'; (ii) these atoms are somehow abstract entities with respect to these combinations ('worlds'), which are thus what is actually primary.

Now suppose (a) that 'atoms' here are thought of on the model of 'things' in the Tractatus and (b) that 'world' is thought of on the model of 'totality of facts' there.

Furthermore, let us make a distinction between different sorts of 'priority' - specifically between (i) 'logical' (ii) 'ontological' and (iii) 'temporal' priority, introducing these in the following way, (i) A is 'logically' prior to B if and only if the constitutive properties of A determine the logical possibility of $B$ (for example, the system of natural numbers is logically prior, in this sense, to the system of real numbers). (ii) A is 'ontologically' prior to B if and only if $B$ really exists (that is, is what makes a certain statement true) only if A really exists (for example, atoms are ontologically prior to molecules). (iii) A is 'temporally' prior to B if and only if A exists before (in the temporal sense) B does (for example, a certain bullet is temporally prior to the wound it causes). These characterisations are certainly rough and ready, but if they serve to help clear up the exegetical problem under consideration then this does not matter.

Using this apparatus, we may say that (a) 'atoms' are prior with respect to (b), a 'world' in sense (i), but not in either sense (ii) or sense (iii). We may also say that (b) is prior with respect to (a) in both sense (ii) and sense (iii) but not in sense (i).

In other words, (a) may be said to be 'analytically' prior but not 'existentially' so, whereas the reverse is true of (b). To borrow terminology from Hume, what is in question here is that (a) are 'distinct' but not 'separable': there is, between them only what he calls a 'distinction of reason'. ${ }^{45}$ In such terms, (a) may well be described as 'abstract', insofar as, since there are different possible

${ }^{45}$ Treatise of Human Nature, Bk I., Pt I, sec. VII and Pt II, sec. IV (Selby-Bigge edition, pp. 24f, 43). 
worlds, they may, for various reasons, be considered in isolation only in abstraction from the combinations in which they always actually occur. ${ }^{46}$ Taking an image from Lucretius, though using it to make a somewhat different point, atoms might be thought of as, in some respects, like the letters of an alphabet, which have their primary existence only in the words (here thought of as the analogy of facts) which they make up, though they may be, for certain purposes, considered in isolation from those words. That is, letters may be regarded, metaphorically, as linguistic atoms. ${ }^{47}$

The original exegetical problem may be diagnosed as arising from a confusion between these contexts of 'priority' The confusion which must surely be sheeted home, in the final analysis, to Althusser's maladroit presentation at this point, for this makes it entirely natural to take Althusser to mean that there exist first of all - temporally 'first' - separate atoms which only afterwards - temporally 'afterwards' - combine into a 'world'. However, on the present interpretation, 'before' here should be taken rather in a non-temporal, 'logical', 'analytical' sense.

\section{The problem about the 'swerve'}

This was the problem (see Section III above) of reconciling two positions: (i) what gives rise to an 'encounter' is an (aleatory) 'swerve' of atoms from primordial rectilinear, parallel motions, (ii) the 'swerve' is prior to rectilinear motion. What has been said in the preceding subsection furnishes the materials for solving this problem in the following way. Swerves are responsible for encounters between atoms, and encounters, if they last, produce those

46 Though 'things' /'objects' are 'abstract' with respect to their combinations in 'facts' /'states of affairs' which alone exist independently, they are not 'abstract' in the way in which, to recur to a distinction in Althusser's earlier work, which is preserved in the later, 'theoretical' 'objects' are abstract with respect to real objects. 'Things' are as real as 'facts', they belong to the same ontological 'category', since the first are constituents of the second; they are both, in terms of the second pair, 'real objects'. However, both 'real' and 'object' in 'real object' are categorically different, respectively, from both 'theoretical' and 'object' in 'theoretical object'. 'Theoretical objects' are necessary for the purpose of referring to, analysing both 'facts' and 'things'. In this regard, there would seem to be a relation to the idea of 'minimal parts' (Epicurus: Elachista [Letter to Herodotus, 36-59], Lucretius: Minimae partae, minima [1992, 1, pp. 599-634, 2, pp. 478-99]), that is, those parts which an atom must have, since it has magnitude, but which are, qua parts of actually indivisible atoms, really inseparable from one another, and can be separated only in thought.

47 See Lucretius 1992, 1, pp. 196-7, 823-5, 912-14; 2, pp. 1013-18. The comparison has even more force in Lucretius, since in Latin elementa (like stoicheia in Greek) means both physical elements and letters of the alphabet. 
combinations of atoms which are called 'worlds'. But it is the latter which are ontologically prior and, in this sense, swerves have ontological priority over the rectilinear, parallel motions with respect to which they are described as 'swerves'. Furthermore, calling on the second clue to solve our exegetical problems alluded to in the first section of Section IV above, namely, Althusser's thesis that philosophy works exclusively through metaphor, it may be suggested that talk of the rectilinear, parallel motions serves to express the fact that the properties of the 'atoms' understood as 'abstract', isolated objects do not determine specific combinations or 'worlds'. From this perspective, those motions are, considered from an ontological point of view, as 'abstract' as the 'atoms' themselves.

Finally, we saw that a 'swerve' was said to be a 'nothing'. This may also be explicated as a metaphor along the preceding lines. For, since the swerve is what is ontologically prior, it is only in the logical sense of priority that a swerve is a movement away from a prior parallel 'motion'.

\section{The problem of the determinants of a 'world'}

A further problem of interpretation arose in the subsection 'A problem about the determinants of a "world"' in reconciling two positions: (i) encounters are totally aleatory and atoms are purely abstract; (ii) atoms have 'affinities' with one another, dispositions to combine, as it were, which pre-exist encounters, so that not just anything can arise as a result of an encounter.

This problem can be solved along the above line of interpretation, as follows. 'Things' have 'internal' properties which constitute their 'form', and constrain, though in no way determine, their 'external' properties (given by the facts in which they happen to occur); the 'internal' properties thus determine, to borrow Althusser's own language in another place, the 'limits of variation' of facts, those which are logically possible. Similarly, atoms qua units of analysis have such internal properties and these are the ones which constitute the 'affinities' of atoms towards one another. With respect to the 'internal' properties of atoms, they are 'distinct' but not 'separable', though the atoms with such properties may combine in many different ways - consistent with those properties - conferring on them their 'external' relations.

Furthermore, all this is consistent with the passage quoted above in which Althusser says that nothing in the elements 'prefigures' the character of an encounter between them: the character of the elements is consistent with many different outcomes. But, an outcome having occurred, then 'determinations' 
of these elements are 'assignable' by 'working backwards' from that outcome, that is, by a regressive inference. The natures of the elements put certain limits on what can result from their encounter but does not determine the character of what may occur within those limits. The elements of the encounter only become 'elements of the encounter' in the encounter itself: before that encounter, they are only what has been called above 'virtual' elements of that encounter, because their characteristics prior to the encounter are what may be called dispositional and in this sense those elements are not fully determinate.

\section{Remarks supplementary to the preceding section}

\section{Introductory}

The preceding three paragraphs have sketched in the briefest way proposed solutions to the exegetical problems posed in Section III above. But what has been said there, and in the preceding Section IV, suggest some further questions of exegesis and development of what Althusser says about aleatory materialism, particularly taking into account the thesis of the essentially metaphorical character of philosophical ideas, and also making use of some of his remarks on one of the central figures in his later work, namely, Machiavelli, in whose thinking, he writes, a philosophy is present, 'a "materialism of the encounter", thought by way of politics'. ${ }^{48}$

\section{'Atom'}

(a) 'Atom' must certainly be taken metaphorically, that is, not in the literal sense of an item in the repertory of physics, but in the sense of an ultimate

${ }_{48}$ Althusser 1994b, p. 546. Through his encounter with Machiavelli, he writes, 'I was to experience the fascination of fascinations. ... He is, without doubt, much more than Marx, the author who has fascinated me the most' (Althusser 1997, pp. 13-14). The book Machiavelli and Us, published only posthumously in Althusser 1999, was written for the most part during 1971-2, but Althusser revised it from then until 1986. It is of the greatest interest to follow, with the help of the editorial notes, how the author brought the earlier text little by little into line with his later aleatory materialism. In the final paragraph, added in 1986, Machiavelli is called 'the greatest materialist philosopher in history' and 'the most incisive in materialist philosophy' (Althusser 1999 , p. 103). On the primacy of political philosophy in Althusser's philosophical thought, see note 2 above. It is plausible to conjecture that Althusser's aleatory materialism and his studies of Machiavelli developed hand in hand. (There is scope for a rich study here.) 
unit of analysis in the domain in question. Thus Althusser writes, 'the atom, in its "fall", [is] the simplest figure of individuality". ${ }^{49}$

(b) This may be taken in connection with the following passage: '. . . that there exist only singular individuals wholly distinct from one another is the basic thesis of nominalism ... [and nominalism] is materialism itself ${ }^{\prime}{ }^{50}$ If the interpretation of aleatory materialism offered so far is to be followed here, 'singular individuals' should be thought of not as particular objects in the ordinary sense, but as facts.

(c) In the history of atomism, and in particular in the context of Epicurean atomism in which Althusser roots aleatory materialism, the term 'atom' carries the connotation (indicated indeed by its etymology) of an absolutely, unconditionally, non-contextually ultimate unit of analysis. ${ }^{51}$ This is also suggested by the connection with the Tractatus doctrine of things as 'simples'. But this would seem to rule out a world of unlimited complexity, and such an a priori restriction can surely be no part of an aleatory materialism. ${ }^{52}$

However, this problem can be taken care of by contextualising the idea of 'atom' or 'simple' in the spirit - indeed along the lines - of Wittgenstein's later thought..$^{53}$ Thus, some item is an 'atom' in a certain context if it is not subject to further analysis at least in that context. For instance, actual atoms are the 'atoms' of chemistry at a certain level of study. In other words, what counts as a 'simple' is determined by linguistic-theoretical context, though, of

${ }^{49}$ Althusser 1994b, p. 561.

50 Althusser 1994d, p. 46f. Cf. Althusser 1994e, p. 217: 'Marx taught me that nominalism was the royal road to materialism. In fact... I can think of hardly any more profound form of materialism than nominalism.' (No reference is given to Marx here, but it is probably an allusion to his discussion of the history of materialism in The Holy Family where he calls nominalism 'the first form of materialism' [Marx-Engels, Collected Works 4. 127/MEW 2: p. 135].) There is an even stronger endorsement of nominalism in the pages omitted from Althusser 1994e: 'nominalism is not the royal road towards materialism but the only conceivable materialism in the world' (Althusser 1997, p. 11). It may be noted that this seems to represent a change of mind, from Althusser 1976 in which Althusser writes that if the distinction between real objects and theoretical objects 'is not solidly supported, it may lead to nominalism, even to idealism. It is generally agreed that Spinoza fell into nominalism' (p. 192). This is even more curious in the light of the fact that earlier in the same book (p. 137) he writes of Spinoza 'as a good nominalist' and adding parenthetically that 'nominalism, as Marx recognised, could then be the antechamber of materialism'.

${ }^{51}$ See the remarks on the Epicurean doctrine of 'minimal parts', note 46 above.

52 See Lenin on 'the inexhaustible electron', Lenin 1962, p. 262.

${ }^{53}$ See Philosophical Investigations, I, Sections $46 \mathrm{ff}$. 
course, that having been determined, what is true of these 'simples' is determined by the way the world is.

(d) The idea of 'internal' properties in the Tractatus has been generally found to be a very obscure one. However, it is fairly clear that they are in some sense thought of in ontological mode - that is, 'atoms' have such properties inherently, independently of descriptions, which are in fact determined by them. This inevitably means that there are, in some sense, de re necessities, even if only in the infra-factual context. This would seem to be incompatible with at least the spirit of Althusser's resolute nominalism.

However, this problem can be avoided by again following the lead of Wittgenstein, this time the later Wittgenstein's critique of essentialism about linguistic meaning, ${ }^{54}$ which entails relativising the 'internal' properties to the language in which their designators occur. For instance, it may be said that it is an 'internal' property of a 'Newtonian' atom that it has, at the same time, a precise position and momentum ascertainable to (in principle) any desired degree of accuracy; that is, if this is not true of a certain physical item (for example, an 'electron' as this is understood within quantum theory), then the latter is not properly describable as a 'Newtonian atom'.

\section{'Taking hold'}

As has been seen, Althusser frequently compares the way in which atoms bond with one another (so to speak) to form 'worlds' (on the present interpretation: facts and complexes of facts) with the way in which water turns into ice, milk curdles or mayonnaise thickens, the common verb used here (prendre) having been (very inadequately) brought over as 'to take hold'. The metaphor is in fact a very curious one, and its point not at all clear. The suggestion may be hazarded that it has a broadly similar one to that of the Tractatus metaphor which likens the connection of things in a fact with the links in a chain. It will be remembered that this is meant to signify that the connection in question is immediate, that is, does not exist by virtue of something else: that the links form a chain is a direct consequence of their individual natures and their being in a certain spatial relation to one another. Then the 'taking hold' metaphor may be taken to signify that just as, to cite one example, water simply becomes ice when it is cooled to a certain

\footnotetext{
${ }^{54}$ Blue and Brown Books, pp. 17f, Philosophical Investigations, I, Sections 66f.
} 
point - no further bonding agent is required - so nothing is needed to bond or 'cement' atoms which have been involved in an encounter into an (at least relatively) enduring complex: it has just happened that way.

\section{'Void'}

This idea functions in Althusser's late thought in at least two ways. (a) The doctrine that the atoms fall in parallel and in a void is a metaphorical way of expressing the view that the external properties of the atoms are purely contingent. That nothing determines them to occur in this rather than that combination..$^{55}$ This is why Althusser underlines the significance of the idea of a void thus: the 'introduction of the void into philosophy ... marks out [désigne] the true materialist tradition in philosophy'. ${ }^{56}$

(b) But this latter remark may be said to have another significance too, namely, that a genuine (aleatory) materialism involves philosophical 'void':

It is a philosophy of the void which not only says that the void pre-exists the atoms which fall in it, but also creates [fait] the philosophical void in order to endow itself existence: a philosophy which, rather than setting out from the famous 'philosophical problems', begins by eliminating them and by refusing to endow itself with 'an object' ... in order to start from nothingness [du néant]. We have then the primacy of nothingness over any form, the primacy of absence (there is no Origin) over presence. ${ }^{57}$

This 'primacy of absence over presence' is elucidated in another passage thus: not as a going-back-towards, but as a horizon receding endlessly ahead of the walker who, seeking out his path on the plain, never finds anything but another plain stretching out before him (very different from the Cartesian walker who has only to walk straight ahead in a forest in order to get out of it, because the world is made up, alternatively, of virgin forests and forests that have been cleared to create open fields: without Holzwege). ${ }^{58}$

That is, to think of change in terms of the metaphor of 'going-back-towards' is to think of it as an approach to a pre-existing somewhere which is the goal of the return, that is, it is to think of it teleologically. The same orientation is

${ }^{55}$ See his remark in Althusser 1994e, p. $241 \mathrm{f}$ that, for Machiavelli, chance $=$ void.

56 Althusser 1993, p. 102.

57 Althusser 1994d, p. 42f, cf. 1994b, p. 547.

58 Althusser 1994b, p. 563f. 
expressed by the metaphor of the walker who, proceeding in a certain definite direction through a forest, inevitably finds himself out of it, since the path is prearranged precisely to enable someone to gain this end. However, the aleatory materialist is conceived of on the metaphor of someone who arrives only at plain after plain, that is, areas bare of topographical determinations. Or, in terms of the other metaphor, the walker in a forest can have no confidence that, by sticking to a definite direction, he will eventually find himself out of it, for it may turn out that he is on a trail leading to a dead-end (Holzweg - cf. Heidegger) within the forest.

\section{Machiavelli: atom, void, swerve, encounter}

Machiavelli's sixteenth-century Italy was a people divided but fervent, fragmented into small obsolete states, engaged in generalised but disorderly revolt against foreign pillage and occupation, but with profound latent aspirations towards unity. 'In sum, an atomized country, every atom of which was descending in free fall without encountering its neighbour. ${ }^{59}$

Machiavelli's project was to think the conditions for the constitution of a national state. All the circumstances favourable to imitate France and Spain were present but without connection with one another: 'It was necessary to create the conditions for a swerve, and thus an encounter, if Italian unity was to "take hold". ${ }^{60}$

Machiavelli believed that none of the existing states and their princes (above all none of the papal states) could create these conditions. Unification would be achieved only on the condition that the swerve and hence the encounter take place in a 'void' which is here represented by, on the one hand, the namelessness both of the right man, the 'Prince', and of the corner of Italy in which the encounter is to take place. The encounter depends on the nameless man installing himself somewhere in Italy and who, starting from this atomic point, little by little assembles Italian states around him in the great project of bringing about a national state.

This is a completely aleatory line of reasoning, which leaves politically blank both the name of the Federator and that of the region which will serve as starting-point for the constitution of this federation. Thus the dice are tossed

59 Althusser 1994b, p. 544.

${ }^{60}$ Ibid. 
on the gaming table, which is itself empty (but filled with men of valour). .... A man of nothing who has started out from nothing starting out from an unassignable place: these are, for [Machiavelli], the conditions for regeneration. ${ }^{61}$

... [T] his new man is a man of nothing, without past, without titles or burdens, an anonymous man, alone and naked. ${ }^{62}$

This silence about the identity of the Prince and of the place is a political condition of the encounter. Encountering 'Fortuna' (chance), it is necessary that the Prince have the virtù to utilise it for the realisation of his destiny. But it is essential that there be 'nothing' standing in his way. That the Prince is 'alone and naked' means that he is

free, without determination ... that bears down on him and imped[ing] the free exercise of his virtù. Not only is he like a naked man, but he finds himself intervening in one place as anonymous and as stripped of every outstanding social and political determination which could impede his action. ... ${ }^{63}$

It is in the political void that the encounter must come about, and that national unity must 'take hold'. But this political void is first a philosophical void. No Cause that precedes its effects is to be found in it, no Principle of morality or theology (as in the whole Aristotelian political tradition ...); one reasons here not in terms of the Necessity of the accomplished fact, but in terms of the contingency of the fact to be accomplished ... all the elements are both here and beyond [là et au-delà] . . but they do not exist, are only abstract, as long as the unity of a world has not united them in the Encounter that will endow them with existence. ${ }^{64}$

The elements are thus real enough insofar as they exist in various combinations but 'abstract' with respect to being conditions of Italian unity, because they are not intrinsically such conditions: they only become such in the context of their being brought together. It is not as though it is part of their nature that they should contribute to Italian unity, though, of course, they could not turn out to be such without already having a determinate character which is also manifested in the circumstances which obtain before the encounter.

\footnotetext{
${ }^{61}$ Althusser 1994b, pp. 544, 545.

62 Althusser 1997, p. 15.

63 Althusser 1997, pp. 14-15.

${ }^{64}$ Althusser 1994b, p. 546.
} 
... in this philosophy, there reigns an alternative: the encounter may not take place, just as it may take place. Nothing decides the matter, no principle of decision predetermines this alternative, which is of the order of a game of dice. 'A throw of the dice will never abolish chance.'

Furthermore:

A successful encounter, one that is not brief, but lasts, never guarantees that it will continue to last tomorrow rather than come undone. Just as it might have not taken place, it may no longer take place. ... In other words, nothing ever guarantees that the reality of the accomplished fact is the guarantee of its durability. Quite the opposite is true: every accomplished fact... like all the necessity and reason we can derive from it, is only a provisional encounter, and since every encounter is provisional even when it lasts, there is no eternity in the "laws" of any world or any state. History here is nothing but the permanent revocation of the accomplished fact by another undecipherable fact to be accomplished, without our knowing in advance whether, or when, or how the event that revokes it will come about. Simply, one day new hands will have to be dealt out, and the dice thrown again onto the empty table. ${ }^{65}$

If, by chance, the encounter between fortune and virtù does in fact take place, then, for it to be lasting, 'the Prince has to learn to govern fortune by governing men' ${ }^{66}$ In order to do this, the Prince must learn to be evil, but in all circumstances he must know how to appear to be good, to possess the moral virtues which will win over the people. Thus the Prince should be like the Centaur of the ancients, who was both man and beast. But the beast is twofold, at once lion and fox. However, ultimately, it is the fox who governs everything. For it is the fox who has the Prince manufacture a popular (ideological) image for himself, which answers to his interests and to the interests of the 'little people':

the Prince is governed, internally, by the variations of this other aleatory encounter, that of the fox on the one hand and the lion and man on the other. This encounter ... has to last long enough for the figure of the Prince to 'take hold' among the people ... i.e., to take form. ... ${ }^{67}$

\footnotetext{
65 Althusser 1994b, pp. 546f.

${ }_{66}$ Althusser 1994b, p. 545 - cf. Althusser 1997, pp. $16 f$.

67 Althusser 1994b, p. 546.
} 
... the quiet instinct of the fox... is in fact the instinctive intuition of the conjuncture and of possible fortune to be seized: a new 'encounter' but this time controlled and prepared as in advance. ${ }^{68}$

Machiavelli "thinks of the fox not in terms of its internal nature as "cause" but only in its effects of semblance'. ${ }^{69}$

\section{Aleatory materialism: necessity and law}

We have seen that 'every encounter is aleatory [in] its origins (nothing every guarantees an encounter) . . every encounter might have not taken place'.$^{70}$ Furthermore, 'every encounter is aleatory ... in its effects', ${ }^{\prime 1}$ because the characters of the elements do not determine a unique outcome of whatever encounter in fact takes place between them. Indeed, as we have also seen,

no determination of these elements can be assigned except by working backwards from the result to its becoming, in its retroaction.... That is, instead of thinking contingency as a modality of necessity, or an exception to it [comme modalité ou exception de la nécessité], we must think necessity as the becoming-necessary [le devenir-nécessaire] of the encounter of contingents ... ${ }^{72}$

To take the view being rejected first, it is clear enough what is meant by the idea of contingency being an 'exception' to necessity, namely, (i) that the two are incompatible and (ii) that necessity is the rule. However, it is by no means clear what is or could be meant by the assertion that contingency is a 'modality' of necessity, unless it is the idea that necessity shows itself at work, manifests itself, as it were, in the field of contingency, for instance, by determining value of a variable which is dependent upon a contingent independent value of another variable. This aside, what, more precisely, is meant by the positive view affirmed here, namely, that of 'necessity as the becoming-necessary of the encounter of contingents'?

An answer to this question is set out in a slightly later passage which ties in necessity with lawfulness:

68 Althusser 1997, p. 16.

69 Althusser 1997, p. 17.

Althusser 1994b, p. 566.

${ }_{11}$ Althusser 1994b.

72 Althusser 1994b, p. 566 - cf. Althusser 1994d, p. 42. 
It will be granted that no law presides over the encounter in which things take hold [la rencontre de la prise]; but, it will be objected, once the encounter has 'taken hold', that is, once the stable figure of the world, of the only existing world (for the advent of a given world obviously excludes all other possible combinations), has been constituted, we have to do with a stable world in which events, in their succession, obey 'laws' ... the world, our world [born of] the encounter of atoms ... is subject to rules ... it is ... a fact... that there is order in this world and that knowledge of this world comes by way of knowledge of its 'laws' ... and the conditions of possibility, not of the existence of these laws, but only of knowledge of them. ${ }^{73}$

At least two points are made here. (i) Though there are no laws (formulations of necessities) which explain the coming-to-be of a world, once the world has come about, there are, contingently, stabilities in its working, laws which may be said to be necessary and used in explanations of particular features of it. The existence of order in the world is not a result of the existence of laws; rather, the converse is the case. (ii) A corollary of this is that there are no 'conditions of possibility' of the existence of the laws themselves (for instance, as in Descartes, the will of God). However, there are such 'conditions of possibility' of knowledge of these laws. It may be remarked that this last point is very puzzling in the light of Althusser's explicit rejection ${ }^{74}$ of the Kantian idea of transcendental 'conditions of the possibility' of knowledge, in favour of the idea that knowledge is always produced within practices which have their own contextually determinate conditions.

The passage continues:

... the necessity of the laws that issue from the taking-hold induced by the encounter is, even at its most stable, haunted by a radical instability, which explains something that we find it very hard to grasp ... that laws can change: not that they can be valid for a time but not eternally . . . but that they can change at the drop of a hat, revealing the aleatory basis that sustains them, and can change without reason, that is, without an intelligible end. ${ }^{75}$

The laws so formed are said to be 'haunted by a radical instability'. Why 'haunted'? Perhaps, in one sense, because of their origin: the fact that a law

${ }^{73}$ Althusser 1994b, pp. 567f.

${ }^{74}$ See e.g. Althusser 1997, p. 3 and Althusser 1993, pp. $108 \mathrm{f}$.

75 Althusser 1994b, pp. 568f. 
is an outcome of a wholly aleatory situation has, as it were, died and been buried in the appearance of unconditional necessity which now attaches to them, but its origin continues to exist as, so to speak, a perturbing spirit. The latter is denegated, as it were, in people's resistance to recognising that such laws as they are have only conditional fields of application: that they may change over time or hold only for certain domains and not others. ${ }^{76}$

\section{Laws and 'constants'}

\section{Introductory}

Though the idea of 'law' as so far presented offers much material for further discussion, this may be set aside here, except to the extent that it is involved in a consideration of the problem of the distinction which Althusser makes in several places between laws and what he calls 'constants' (sometimes 'invariants'). The problem is a very knotty one. I shall first assemble the principal textual protocols from his two main presentations, with only that minimum of analysis necessary to make somewhat clearer and more explicit what these assert, on the surface, so to speak, next bring these two together in summary, then go over to a synoptic analysis, and lastly bring the whole discussion together.

\section{The presentation in Althusser 1994d}

In Althusser 1994d, Althusser remarks that the aleatory materialist
records sequences [séquences] of aleatory encounters... [he] can conduct experiments [expériences] on the consecutions [consécutions] of aleatory sequences that he has been able to observe, and can (like Hume) work out laws of consecution, 'customary' [habituelles] laws or constants, that is, structured theoretical figures [figures théoriques structurées]. These experiments will lead

\footnotetext{
${ }^{76}$ The passage quoted seems to me to be ambiguous about the possibility of 'laws' changing over time rather than with respect to domain: it is not entirely clear whether the former is being ruled out or whether what is meant is just that this is not only what is meant. The general thrust of Althusser's doctrine of aleatory materialism would seem to be wholly hospitable to the idea of variation of laws over time. Certainly, it has been the subject of discussion at least since C.S. Peirce, through Poincaré ([1913]) to the present day (e.g. Balashov 1992).
} 
him to deduce universal laws for each type of experiment, depending on the kind of beings that it took as its object: that is how the natural sciences proceed. Here we ... meet the term and function of 'universality' ${ }^{77}$

Understanding just what this passage means faces many difficulties, and it is necessary to proceed cautiously.

It will be best to start by listing, simply in the order in which they occur, a number of terms used, after which the question of their meanings (including interrelations) can be posed. The terms in question are the following: (i) 'sequences', (ii) 'consecutions' (of sequences), (iii) 'laws of consecution', (iv) 'customary laws', (v) 'constants', (vi) 'structured theoretical figures', and (vii) 'universal' /'universality', (viii) 'kind of beings'.

(i) and (ii) would seem to mean different things, if only because (ii) is said in some sense to characterise (i): the passage speaks of 'the consecutions of . . . sequences' (emphasis added).

What then does (i) mean? The language used - 'records', 'observes' - may be taken to suggest that it refers to sequences of events as ordinarily, more or less immediately observed - these are the subject-matter, the raw material of experiment.

If this is at least broadly correct, then what does (ii) mean? It is at least very doubtful whether the passage allows of any conclusive or even reasonably satisfactory answer to this question. However, in the light of (iii), the suggestion may be hazarded (the word is used advisedly) that (ii) may refer to that which in (i) is more than 'accidentally' sequential, though only so by virtue of being derivative from other sequences. For instance, the sequence of someone sneezing and the collapse of a building nearby may be described as accidental simpliciter, whilst the sequence of day and night is not accidental, though only so by virtue of its being a consequence of non-accidental sequences.

Some light is cast on the problem of interpretation here by a passage in another of Althusser's writings of this period. (It occurs in the context of a discussion of Machiavelli.) Here, Althusser contrasts thinking 'in terms of cause-effect as consequence [la conséquence cause-effet]' with thinking 'in terms of factual consecution [la consécution factuelle] . . . between "if" and "then"'. The first is said to be a feature of 'the whole Platonic and Aristotelian tradition'. The second is said to be 'already present in black and white in the Sophists

77 Althusser 1994d, p. 65. 
and Epicurus, combated for this serious reason by Plato and developed at length by the Stoics', and 'recovered' by Machiavelli in 'a true revolution in ways of thinking which will open the way to the whole of modem experimental science'. In the first case, it is 'a matter of an effect's being a consequence of a cause [d'une conséquence de cause ... à effet] (or principle or essence), of derivation or logical implication', in the second, of 'a simple consecution of conditions, "if" signifying given factual conditions, that is, the factual conjuncture without originating [originaire] cause, "then" designating what observably and reliably follows on the conditions of the conjuncture'.$^{78}$

In sum, (ii) are represented in the form of contingent conditional statements, discovered by experiment on (i). They may be about particular items ('If Fido barks the baby cries'), but are at least implicitly (vii) universal relating to (viii) kinds of rather than particular things. All this is held to pertain to the domain of natural science.

Now, what of (iv)-(vi)? To start with, whatever they may mean, (v) and (vi) are pretty clearly meant to be synonymous. But (a): is (iv) meant to be in opposition with (iii)? And (b): what is the force of 'or' between (iv) and (v)? Does it indicate a mere verbal alternative as between (iv) and (v) or a genuine conceptual disjunction? It is at least plausible to argue that the answer to (a) is yes, on the ground that (iii) is explicitly associated with the name of Hume and (iv) may be taken to be implicitly thus associated through the use of 'customary'. There is no basis for an answer to (b) in the passage under discussion, either grammatically or by reference to what might be meant by (v), but the immediately following passage makes it fairly clear that (iv) (therefore (iii)) and (v) are indeed quite different. Let us now consider this passage.

In it, Althusser asks to start with what the situation is in a field where 'it is not a question of objects which repeat themselves indefinitely and on which experiments can be repeated and rerun from one corner of the world to the other by the scientific community'.$^{79}$ Here, the aleatory materialist 'who is attentive to "singular" cases cannot state 'laws' about them, since such cases

\footnotetext{
${ }_{78}$ Althusser 1993, pp. 99, 100. It may be noted that Althusser's much-admired Spinoza was surely a consequentialist in this sense: he identifies causa and ratio (e.g. Ethics, preface to Book IV) so that an effect follows from a cause like a conclusion from its premises (e.g. Ethics, Book IV, Prop. 57, Schol.).

${ }^{79}$ Althusser 1994d, p. 65.
} 
are singular/concrete/factual and are therefore not repeated, because they are unique' ${ }^{80}$

The contrast with the preceding sort of field concerns, then, (i) the subjectmatter: not 'kinds' of things, forms of repetition, but 'cases' which are 'singular', 'factual', 'concrete', (ii) the consequence that experiment is not applicable to them, since experiment involves repetition, and (iii) the further consequence that it is not possible to affirm universal laws about them.

Nevertheless, Althusser continues, the aleatory materialist can

single out 'general constants' among the encounters he has observed, the 'variations' of which are capable of accounting for the singularity of the cases under consideration, and thus produce both knowledge of the 'clinical' sort as well as ideological, political and social effects. Here we again find not the universality of laws (of the physical, mathematical or logical sort), but the generality of the constants which, by their variation, enable us to apprehend what is true of such-and-such a case. ${ }^{81}$

But what, more specifically, are 'constants' as distinct from 'laws', and what is the 'generality' which attaches to the first as distinct from the 'universality' which attaches to the second?

A clue as to the nature of 'constants' is offered, in the passage from which the previous quotations have been taken, by Althusser's claim ${ }^{82}$ that the idea is exemplified by Lévi-Strauss in his treatment of 'cosmic myths of primitive societies'. However, this is a fairly enigmatic allusion, and it will be best, in attempting to cast further light on the matter, even at the expense of what is here a digression, to look at a passage earlier in Althusser 1994d where Althusser discusses the nature of history.

There are, he writes, 'two types of histories, two histories':

to start with, the History of the traditional historians, ethnologists, sociologists and anthropologists who can speak of 'laws' of history because they consider only the accomplished fact of past history. History, in this case, presents itself as a wholly fixed object all of whose determinations can be studied like those of a physical object, an object that is dead because it is past... an accomplished, unalterable, petrified history from which one can draw

\footnotetext{
${ }^{80}$ Ibid.

${ }^{81}$ Althusser 1994d, pp. 65f.

82 Althusser 1994d, p. 65.
} 
determinant, deterministic statistics. It is here that we can locate the source of the spontaneous ideology of the vulgar historians and sociologists, not to speak of the economists. ${ }^{83}$

The other type of history is what is denoted by the German word Geschichte, which designates not accomplished history, but history in the present [au présent], without doubt determined in great part by the already accomplished past, yet only in part, for a history which is present, which is living, is also open to a future that is uncertain, unforeseeable, not yet accomplished, and therefore aleatory. ${ }^{84}$

Althusser goes on to say that Marx did not employ the term 'constant', but rather

an expression of genius: 'tendential law', capable of inflecting (but not contradicting) the primary tendential law, which means that a tendency does not possess the form or figure of a linear law, but that it can bifurcate under the impact of an encounter with another tendency and so on ad infinitum. At each intersection the tendency can take a path that is unforeseeable because it is aleatory. ${ }^{85}$

The interviewer then asks, 'Could we sum this up by saying that present history is always that of a singular, aleatory conjuncture?' Althusser replies:

Yes, and it is necessary to keep in mind that 'conjuncture' means 'conjunction', that is, an aleatory encounter of elements - in part, elements that exist, but also unforeseeable elements. Every conjuncture is a singular case, as are all historical individualities, as is everything that exists [my emphasis, W.S]. [The objects of] the history of Marxism or psychoanalysis ... belong not to accomplished history but to Geschichte, to living history, which is made of, and wells up out of, aleatory tendencies and the unconscious; this is a history whose forms have nothing to do with the determinism of physical laws. It

${ }^{83}$ Althusser 1994d, pp. 44f. Cf. 'A truly materialist conception of history implies that we abandon the idea that history is ruled and dominated by laws ...' (Althusser 1994d, p. 32), and in particular dialectical laws. 'The dialectic (not only in the form given it by Engels, the science of the laws of movement of matter) is more than doubtful, indeed it is harmful [néfaste], that is, always more or less teleological' (Althusser 1994d, pp. 128f).

${ }_{84}$ Althusser 1994d, p. 45.

${ }^{85}$ Ibid. 
follows ... that aleatory materialism [is] required to think the openness of the world to the event, the as-yet-unimagined [l'imagination inouïe], and also all living practice, including politics. ${ }^{86}$

These passages offer a great many puzzles and much material for analysis. But, for the moment, let us just sum up some of the main points relevant to our theme. (i) A fundamental distinction is made between two sorts of subjectmatter of knowledge, namely, (a) kinds of items which have recurrent instances and (b) 'cases', items which are singular, concrete, unique. (ii) (a) form the domain of 'laws' which are 'universal', arrived at by way of experiment, this domain being the province of the 'natural sciences'. (iii) (b) form the domain of 'constants', which are 'general', not arrived at by way of experiment and exemplified by the provinces of history and psychoanalysis. (iv) Examples of constancies are Lévi-Strauss's 'cosmic myths' and, from the Marxist tradition, are class struggle with respect to history and Marx's notion of 'tendential law'.

${ }^{86}$ Althusser 1994d, pp. 45f.

... not only the world of life... but the world of history too, congeals [se fige] at certain felicitous moments, with the taking-hold of elements combined in an encounter [que conjoint une rencontre] apt to trace such-and-such a figure ... such-and-such a species, individual, or people. Thus it happens that there are aleatory men or 'lives' ... . and their 'works', and the great figures of the world to which the original 'throw of the dice' of the aleatory has given their form, the great figures in which the world of history has 'taken form'.... This makes it all too clear that anyone who took it into his head to consider these figures, individuals, conjunctures or states of the world as either the necessary result of given premises or the provisional anticipation of an end would be mistaken, because he would be neglecting the fact (the 'Faktum') that these provisional results are doubly provisional, not only in the sense that they will be superseded, but also in the sense that they might have never come about [advenir], or might have come about only as the effect of a 'brief encounter', if they had not arisen on the happy basis of a stroke of good fortune which gave their 'chance' to 'last' to the elements over whose conjunction it so happens (by chance) that this form had to preside. (Althusser 1994b, p. 567)

The passage concludes:

This shows that we are not - that we do not live - in Nothingness [le Néant], but that, although there is no Meaning to history (an End which transcends it, from its origins to its term), there can be meaning in history, since this meaning emerges from an encounter that was real, and really felicitous [une rencontre effective et effectivement heureuse] -, or catastrophic, which is also a meaning [qui est aussi du sens]. (Althusser 1994b, p. 567)

Thus there is no meaning to history as a whole, transcendent to history, but, as it were many meanings immanent to history. 


\section{The presentation in Althusser 1993}

Passages relevant to the theme under discussion occur in Althusser 1993/1997. They have to do, in the first place, with aspects of what Althusser considers he learned from Spinoza and, correlatively, with what he considers Spinoza has to teach us. These references to Spinoza will be, where possible, omitted in the following citations both in the interest of brevity and, much more importantly, because what is mainly relevant here is what Althusser has to say in general terms.

... [in] history ... and ... psychoanalysis ... there are only 'cases'. ... Marx ... wrote that there is never production in general, labour in general, and so forth and that each history is always a singular 'case' ... [we] never encounter 'the same case' again, but always and uniquely singular, and, therefore, different 'cases'.... In individual and social life [there are only] singularities (nominalisms [nominalismes]), really singular ... ${ }^{87}$

If this is so, then

... how, then, to pretend to draw out consequences that are general, that is, abstract, since every case is concrete, and - as is not true of concrete objects (oak trees, beech trees, plum trees, pear trees, etc., as realisations of the concept 'tree') - one can never abstract from individual singularities in order to reach the abstract concept of the thing itself? ${ }^{88}$

Indeed, the situation is even more serious than this:

... how can one claim to speak about singularity itself in general if one has no previous knowledge of it, if the fact of singularity is not and can never be a 'concept', even its own concept? And Spinoza would himself warn us: he speaks of an intuitio in the case of 'knowledge of the third kind' ... just as the politician speaks of a feel for the conjuncture [le sens de la conjuncture]). How to abstract from whatever singular and therefore not comparable intuitions there are? ${ }^{89}$

However, these singularities are nevertheless universal, for ... [they] ... are as if traversed and haunted by repetitive [répétitifs] invariants or constants - that one can discover [retrouver] under

\footnotetext{
87 Althusser 1997, pp. 8-9.

88 Althusser 1997, p. 8.

${ }^{89}$ Ibid., translation modified.
} 
their singular variations in other singularities of the same species and genus. .... Constants or generic invariants ... arise [affleurent] in the existence of singular 'cases' and... permit their treatment (whether theoretical or practical). ${ }^{90}$

For example, 'Spinoza rediscovers quite naturally in the singular history of the Jewish people a constant that he has treated "in general" in the appendix to Part I [sc. of the Ethics - W.S.] regarding religion in general, and yet there never exists religion in general in Spinoza, any more than production in general ever exists in Marx'. ${ }^{91}$

Althusser goes on to emphasise that these constants/invariants are 'generic and not "general" ... not laws'. As such, they are not subject to 'verification in an abstract, renewable [renouvelable] experimental dispositif, as in physics or chemistry'.

\section{However, their}

repetitive insistence [instance répétitive] permits us to mark the form of singularity in presence and, therefore, its treatment. It is obviously a question here of a test [d'une épreuve] which has nothing to do with experimental methods of proof [preuve] in the physical sciences, but which possesses its rigour, whether it be in the knowledge and treatment of individual singularity (medicine, analysis) or social singularity (history of a people) and action over history (politics). ${ }^{92}$

What is meant here by the distinction between 'épreuve' and 'preuve' is by no means clear. It may be the sort of distinction made in English between something being 'tried out' (tested, assayed) - for example, a car for its safety on the road - and someone being 'tried' on a criminal charge, where what is in question is the truth or falsity of a claim. ${ }^{93}$

This sort of knowledge of the singular (of the relevant generic constant/

${ }^{90}$ Althusser 1997, p. 9, translation modified.

91 Ibid., translation modified.

92 Althusser 1997, translation modified.

93 The following passage may give some further clues to the problem just indicated: '... any "medical", "historical", or "analytical case" is ... singular and at the same time universal. ... The universality of this singular case emerges not from a Popperian verifiable-falsifiable law, but from the fact that certain constants are repeated, appear in every case, and allow one to infer from them the theoretical and practical treatment appropriate in other unique cases. Machiavelli and Marx work in exactly the same way, with a logic that has gone almost unnoticed and which should be developed', Althusser 1994e, p. 241. See also p. 216 and also Althusser 1997, pp. 8-9. 
invariant) is, Althusser says, what Spinoza called 'knowledge of the third kind'. Here

we are never faced with a new object, but simply a new form of relation of appropriation (the word is Marx's) of an object that is always already there since the first kind of knowledge: the 'world', the Lebenswelt of the first kind is elevated while remaining completely the same, [a] concretion of universal singularities in itself.... What changes is never the being itself of things ... but the relation of appropriation that the human subject enters into with them. In this sense, which will be taken up again by Hegel and Marx, every process of knowledge indeed proceeds from the abstract to the concrete, from the abstract generality to concrete singularity. ${ }^{94}$

The last sentence of this passage contains at least one baffling element: Althusser says that 'every' process of knowledge involves knowledge of 'the concrete singularity' in terms of 'generality', whereas, so far, a sharp and fundamental distinction has been drawn between sciences which deal with types of things in 'universal' terms and those which deal with singular cases in 'general' ones. Thus what is said here is completely anomalous in the context of Althusser's foregoing general argument. For the moment, in order to pursue the main line of Althusser's argument, I simply flag the point and shall return to it later.

Finally, he relates this to his earlier account of the production of knowledge:

In my language I have called that very roughly the passage from Generalities I to Generalities III by means of Generalities II; I deceived myself in that the reality envisaged by knowledge [i.e. the product of the process - W.S.] ... is not that of a generality but of a universal singularity. But I was indeed on Spinoza's 'line' by insisting with Marx and Hegel on the distinction between the 'real concrete', therefore the universal singular (all the 'cases' that constitute the world from the beginning of knowledge of the first kind) and the concrete-in-thought that constitutes knowledge of the third kind. ${ }^{95}$

It is now time to sum up the main lines of the preceding passages. (i) In the cases of history and psychoanalysis, we have to do with 'cases', 'singularities' which are unique, concrete. (ii) Since knowledge is, in the nature of the case, abstract, knowledge of 'cases' /'singularities' cannot take the form of general

\footnotetext{
94 Althusser 1993, pp. 9-10.

95 Althusser 1993, p. 10.
} 
concepts/laws, for the latter abstract precisely from the differences which characterise the singularities. Indeed, how can one speak of singularity in general if it is of the essence of the singular to be non-general? (iii) Such knowledge is possible because the singularities are 'traversed' by 'constants'/ 'invariants'. These are not 'general' but 'generic'. (iv) An example of the latter, from Spinoza, is his treatment of religion which is used as a means to knowledge of the Jewish people, an example of the former. (v) This sort of knowledge of the singular cannot be vouchsafed by experiment, which is only applicable to the general. (vi) However, it has its own rigour involving not experimental test but a 'testing out' of the case for the presence of a constant/invariant. (vi) This knowledge of the singular does not have an object different from the singular which is known. The difference resides in a different sort of appropriation, a different sort of relation to the singular. The latter remains as it was, but to start with it is apprehended abstractly, that is, in abstraction from the constants/invariants which 'traverse' it, whilst it ends, as being apprehended, in its representation as a 'concrete-in-thought', in the context precisely of those constants/invariants. This account is similar to Althusser's earlier account of the cognitive appropriation of objects in terms of three 'generalities', except that now the final stage is now called, as it should have been all along, not a generality but a universal singularity.

\section{Bringing together the two presentations}

Both presentations agree on the centrality of a distinction between two sorts of subject-matters, namely, that between (1) the sort of recurrences which are dealt with by the sciences based on experiment and (2) the singular, concrete, unique 'case'. The form of knowledge appropriate to the first is $\left(\mathrm{l}^{\prime}\right)$ laws and to the second $(2$ ') 'constants' which are also called, in the second presentation, 'invariances'. (For the sake of brevity, the first only will be used in what follows.) Althusser's terminology with regard to them is somewhat - and confusingly - different in the two presentations. In the first, he uses 'universality' to characterise $\left(1^{\prime}\right)$ and 'generality' to characterise $(2$ '). In the second presentation, 'universality' characterises both, and 'generality' is used in the sense which 'universality' had in the first. Simply for the sake of clarity, the following will stick to just one consistent terminology, specifically (and fairly arbitrarily) to that of the first presentation. As examples of constants, he adds to those provided in the first presentation that of Spinoza's idea of religion. The second presentation adds more detail to the epistemology of the situation. 
It is now necessary to try to analyse the preceding considerations more carefully.

\section{Althusser's 'constants' and Marx's 'tendential laws'}

The first problem concerns the fundamental dichotomy of subject-matters and forms of knowledge alleged by Althusser in the main line of his presentation. Since 'constant' is the most obvious terminus technicus in the latter, and since it is by no means one whose meaning is clear, an obvious place to start is to tackle the task of getting clearer about it. Since Althusser's characterisation in general terms is unclear, the most hopeful jumping-off point is a consideration of examples he provides.

Of these we have seen that there are four: one from Lévi-Strauss, one from Spinoza and two from Marx. He hardly does more than mention the first two, and, besides, there are obvious advantages in having examples from Marx. So let us look at the second two examples.

The first is class struggle: history understood as Geschichte 'obeys only a constant (not a law): the constant of class struggle'.

This is a puzzling remark for at least two reasons. The first is that everything said about Geschichte so far would seem to apply not only to social history but also to natural history, from cosmology to biological evolution (if the first were to be ruled out on the - arguably quite spurious - ground that it is basically just applied physics, the second surely cannot), and that there is no class struggle in the domain of natural history. The second puzzle arises, even in the domain of social history, as follows. Consider someone as living in a pre-class society. Then, for that person, Geschichte is open, but it does not obey the 'constant' of class struggle, for the simple reason that there are no classes. Furthermore, if we imagine ourselves in a post-class society, Geschichte would not obey the 'constant' of class struggle either.

The second example, namely, Marx's idea of a 'law of tendency', looks much more promising. In considering this in Marx's writings, the obvious place to start is the case of what he quite explicitly calls such a law, namely, the 'Gesetz des tendenziellen Falls der Profitrate' (heading of Part III of Capital, Volume III) - the 'Law of the Tendential Fall in the Rate of Profit' or 'Law of the Tendency of the Rate of Profit to Fall' (translations in Penguin and Moscow editions respectively). Let us see how Marx sets the matter out.

The part in question begins with Chapter 13, entitled 'Das Gesetz als solches' - literally, 'The Law as Such' (rendered 'The Law Itself' in the Penguin 
edition). The law is here derived from certain fundamental features of the capitalist mode of production and says that the law for the latter, 'the rate of surplus-value . . . is expressed in a steadily falling general rate of profit' ${ }^{96}$ That is, there is a functional relation between changes in two variables, the rate of profit and time, such that the former decreases as the latter increases. Marx goes on immediately, 'We shall show later why this drop does not emerge [hervortritt] in this absolute form, but more in a progressive tendency to a progressive fall' (loc. cit., trans. revised). The promised demonstration is given in the following Chapter 14, entitled 'Counteracting Causes' (of which six are listed, beginning with more intense exploitation of labour and reduction of wages below their value). Marx thus calls the law as stated the law in its 'absolute form', which 'emerges' as a 'tendency'. 'Absolute' is used here in its original, etymological sense (ab-solutus) as referring to what exists unconditionally.

It is now possible to hazard a suggestion as to how the preceding may aid the elucidation of what Althusser has to say about 'constants' and knowledge of singulars. The real starting point is a concrete, specific, singular value of the rate of profit. The 'constant' here may be taken to be the 'law of the tendential fall in the rate of profit' 'as such', in its 'absolute' form. The singular case may then be conceived as being 'traversed' by the former, insofar as its cognitive representation is derivable from the constant in conjunction with certain specific instances of various 'counteracting causes', which determine what Althusser calls 'variations'.

In this regard, it must be insisted that the law 'as such' in its 'absolute' form is a purely discursive entity. There is no significant sense in which it can be said to be somehow a part or aspect of the world of real objects, for it is never true of the latter. It is 'true' only of a certain model of real objects, a model defined by the conditions from which it is derived, in other words, it is 'true' of, or 'governs', what is sometimes referred to as a 'pure case'. ${ }^{97}$ The latter has cognitive value to the extent that a 'fit' can be demonstrated, through various procedures, between it and real systems.

This is why a certain terminological exactitude is very important here, specifically, to speak of a 'law of a tendency' and not a 'tendential law', as

\footnotetext{
96 Penguin edition, p. 319/MEW 25: p. 223.

97 The idea of a 'pure case' has roots in everyday thinking, in particular in the idea of what is 'normal'. However, this tends to be confused with the quite different idea of what might be described as what is 'usually' the case. See Suchting 1993, pp. 141f. Also, the 'pure case' should not be confused with Weber's 'ideal-type' (see e.g. Weber 1949); for the distinction between the two, see Nowak 1980.
} 
some writers do. For the latter may well suggest that the law itself is tendential, which does not make sense: either the law holds (of a certain model) or it does not - tertium non datur. To speak of a 'tendential law' is, at a minimum, to run the risk of conflating the law itself, which belongs purely to the domain of 'thought-objects', with real circumstances.

In general, a law of tendency states, briefly, that if a certain state of affairs $F$ obtains, then a certain other state of affairs, $G$, will obtain, 'other things being equal', those other things being at least partly specified (without this the 'law' would be vacuous), though often the 'defeating' or 'saving' clause is left to some extent open. (The latter circumstance is not a defect but an advantage for it provides the law with heuristic power in further inquiry.)

The conclusion indicated by the above is that Althusser's notion of a 'constant' can indeed be given a fairly clear interpretation in terms of Marx's idea of a 'law of tendency' as exemplified paradigmatically in the 'law of the tendency of the rate of profit to fall'.

\section{Marx on the general applicability of the idea of a 'law of tendency'}

Insofar as 'the law of the tendential fall in the rate of profit' is indeed a law, it is, of course, one about socio-historical subject-matter. What about Althusser's further thesis that there is a sharp contrast between, on the one hand, 'general' 'constants', characteristic of (to repeat his repeated examples, history and psychoanalysis) and, on the other, 'universal' 'laws' characteristic of the sciences of nature?

Since Althusser calls upon Marx's notion of a 'law of tendency' in elucidating and exemplifying his notion of 'constant', it is relevant to ask whether Marx himself made such a distinction. Constraints of space make detailed reference to his texts impossible, but a couple of them, which may be made to stand for all, show quite decisively that he did not.

First of all, consider his statement in Capital, Volume I of 'the absolute general law of capitalist accumulation'. 'Absolute' here may be taken, prima facie, to have the same meaning as it had in connection with the law of the tendential fall in the rate of profit. This is confirmed by the immediately following remark. 'It is, like all other laws, modified in its realisation [Verwirklichung] by manifold circumstances' ${ }^{98}$ That is, since it is precisely the

\footnotetext{
${ }_{98}$ Penguin edition, p. 798/MEW 23: p. 674 - translation revised and emphasis added.
} 
existence of such countervailing conditions which makes the absolute law regarding a fall in the rate of profit manifest itself as only a 'tendency', this 'general law of capitalist accumulation' is also only the law relating to a tendency, and this is said to be true of 'all' laws.

Can it be plausibly suggested that Marx is here referring, however implicitly, only to all social laws, ones relating to human history? There is absolutely no textual evidence for this. Moreover, in another place, Marx explicitly compares laws in political economy with those in that paradigm of the natural sciences, mechanics, in this respect.

... Capital is in itself indifferent to the particular nature of every sphere of production.... In reality this fluidity [Flüssigkeit] encounters frictions which cannot be considered further here.... Furthermore, ... that same fluidity of capital assumes a like fluidity or versatility [Variabilität] ... in the capacity for application of labour-power in the worker... Classical economics regards the versatility of labour-power and the fluidity of capital as axioms, and it is right to do so, insofar as this is the tendency of the capitalist mode of production which ruthlessly wins through despite all obstacles.... At all events, in order to present the laws of political economy in their purity, abstraction is made from these sources of friction, as in pure mechanics abstraction is made from the particular frictions that have to be overcome in every particular case of its application. ${ }^{99}$

\section{Independent considerations on the logic of concept-formation and laws}

Let us now consider the matters in question independently of Marx texts after all, Marx could have been wrong in his view about the common character, in the respect indicated, between social and natural laws.

All production of knowledge (at the very least of non-formal knowledge, if there is such a thing as purely formal knowledge) starts with the singular,

99 'Results of the Immediate Process of Production', Appendix to Capital, Volume I, Penguin ed., pp. 1012f, 1014/ Resultate des unmittelbaren Produktionsprozesses (Frankfurt: Verlag Neue Kritik, 1969), pp. 39, 40 (translation revised). All this has, arguably, an important bearing on Marx's reference in the first volume of Capital to the 'natural laws' of capitalist production and his approbation of a passage from a Russian review of the work in which it is said, inter alia, that according to him 'the social movement' is a 'process of natural history' (Penguin edition, pp. 91, 101/MEW 23: pp. 12, 26), and also to his claim, in the ' 1857 Preface' that the economic conditions of production 'can be ascertained with the accuracy of natural science'. But discussion of these matters would take us too far afield. 
unique, 'real concrete' (Marx), and ultimately returns to it in the context of explanation, prediction, testing, control.

Althusser's views about the distinction between natural-scientific laws, characterised by universality and the 'general' 'constancies' proper to non-natural-scientific subject-matters rests, quite explicitly, on a certain account of concept-formation, one which may be called 'Aristotelian' or 'pre-modern' (using this term in both a systematic and historical sense). ${ }^{100}$ According to it, concepts are of classes of things and are formed by abstraction, that is, by omission, in thought, of differences between sets of objects, leaving only common features. This gives a 'nested' hierarchy going 'downwards', from genera the most general, through species, to, ultimately, individual, singular things, from which abstraction has been made, and which are, to proceed 'upwards' in the hierarchy, instances of, successively, species, and of genera.

The post-'Aristotelian' method of cognitive appropriation of the singular, initiated by modern natural science, proceeds in a quite different way. First of all, it focuses, in the first place, not on singulars but on properties of singulars, which in itself removes the latter from the centre of the stage, since the properties are general. This initial step is not the crucial one, however, since the Aristotelian method also does this. What is distinctive about this modern method is the way it treats these properties. What it does in the first place is to set up general relations between them, ${ }^{101}$ and, specifically, constant relations

100 The fundamental source on this matter remains the work of Cassirer - both primarily historical (1922) and primarily systematic (1953, 1928 and 1957, especially Part III). But see also two splendid pieces by Cassirer's student Lewin 1927, 1935, and the books by Burkamp 1927, and Dewey 1929 and 1938.

${ }^{101}$ In the present context, it is worth pointing to Marx's own recognition of the primacy of relations in concept- and theory-formation. Just one particularly explicit passage may be adduced.

In his discussion of the distinction between fixed and circulating capital, he writes: 'It is here a question not of definitions under which things are subsumed. It is a question of definite functions that are expressed in definite categories' (Capital, Volume II, p. 303, Penguin edition/ MEW 24: p. 228 tr. rev.). We have here a correlation between three pairs of contrasts: between (1)(a) 'things' versus (b) 'functions', (2)(a) 'definitions' versus (b) 'categories', and (3)(a) being 'subsumed' versus (b) being 'expressed'. The items in (1) belong to the domain of real objects, those in (2) to that of theoretical objects. (l)(a) may be taken to be individual substances, fundamental to Aristotle's metaphysical scheme, the fixed nature of which are determined by their inherent essences ('formal causes') formulated in (2)(a) (class-concepts), which assign those substances fixed places in the order of being, and in relation to which they stand by virtue of (3)(a). However, for Marx, what is fundamental is not (1)(a), that is, not things with natures independent of the relations within which they stand, but $(1)(b)$, determined by those relations, which may differ according to context, formulated in 
between the variations in these properties, that is, functional relations. Classes of things are then defined, not by omitting from consideration what distinguishes them but by replacing such differences by certain sorts of constants (in the logico-mathematical sense), which, when appropriately filled in, yield the original classes.

This procedure may be most easily understood by an example, and indeed one from elementary mathematics - it is easy to transfer this to the case of non-formal knowledge.

Ancient 'synthetic' geometry studied a number of sorts of figures, including the circle, ellipse and parabola. What was seen as common to them all was that each arises from a distinct way in which a plane intersects a cone. They may thus be regarded as species of the genus 'conic section' under which they are subsumed (individual such forms being similarly subsumed under the relevant species). The geometry of each was worked out separately from one another. Whilst each type of figure may be arrived at by adding a differentia specifica to the genus, this was, as it were, added to the genus from outside it. There was no geometry of conic sections as such.

In modem 'analytic' geometry ${ }^{102}$ there is indeed such a geometry, governed by a completely general equation

(1) $A x^{2}+2 B x y+C y^{2}+2 D x+2 E y+F=0$

From this, equally general theorems may be deduced. Then less general equations may be derived from this one by assigning certain values to one or more of the arbitrary ('parametric') constants $A, B, C, \ldots$ For instance, it is possible thus to derive the equation

(2) $x^{2} / p^{2}+y^{2} / q^{2}=1$

where $p$ and $q$ identify a class of 'foci'. This equation defines, and yields the geometry of what is known as an 'ellipse'.

Finally, the assignment to $p$ and $q$ of particular values (individual constants) relative to an appropriate particular set of abscissae signifies the identification of

(3) a unique ellipse.

(2)(b), which, since they are dependent upon, derivative from real situations, stand to the latter in the relation (3)(b). (Specifically, a physical item is not fixed or circulating capital in itself, but falls under one or other description according to the role it plays in the circuit of capital.)

102 Any standard work on the subject contains the relevant material - e.g. Alexandrov et al. (eds.) 1963, pp. 207-9. 
In Aristotelian terms, (1) may be said to be the genus, (2) a species of (1), and (3) an individual ellipse. But note that (1) does not arise by abstraction from the various species (2), nor (2) by abstraction from its instances (3); on the contrary, (3) arise by specification of (2) and (2) from specification of (1). Whilst, on the Aristotelian theory, the genus has less specific content than either its species, or, a fortiori, the members of the latter (the traditional so-called law of the inverse relation of connotation/intension and denotation/extension), in the above case (1) has the most content of all since (2) and (3) may be derived from it by specifying further what is already implicit in it in the form of arbitrary constants. ${ }^{103}$

Looked at in the context of empirical concept-formation, the question of individuality can best be seen as dealt with by means of the notion of 'constant' of which three general types can be distinguished. (i) Universal constants for example, the velocity of light in vacuo or the electrical charge on the electron - may be seen, in an only superficially paradoxical way, as both (putatively anyway) wholly general but also as wholly individualising, that is, as marking out this 'world' from other logically possible ones. (ii) Arbitrary ('parametric') constants demarcate classes of items within such a 'world'. For instance, a particular sort of element is specified by its constant 'atomic number' (number of electrons orbiting the nucleus of the neutral atom of that element or, equivalently, the number of protons in the nucleus). Subspecies of a specific element may then be marked out in terms of further constants, for example, isotopes in terms of the mass of the atom, determined by the number of neutrons in their nuclei. The general concept 'element' is formed not by omitting differences between kinds in these regards, which would ultimately yield some substantively largely vacuous idea, but precisely by representing kinds of such differences by constants of type (ii), constants which then be replaced by particular numbers. (iii) Individual constants then help to identify strictly unique items; for instance, such such-and-such individual instance of such-and-such an element may be identified in terms

103 See, here, Hegel's three-fold distinction between 'universality', 'particularity' and 'singularity'. That Hegel already gripped the crucial point here emerges from his brilliant but generally neglected remarks on mathematical series in his Science of Logic, especially at p. 647 of the Miller translation. It may be shown that this contains the clue to understanding his otherwise obscure notion of 'concrete universality' (foreshadowed in Spinoza's also obscure idea of 'knowledge of the third kind'), but doing so here would, again, take us too far afield. 
of its spatio-temporal co-ordinates. The qualification 'help' is necessary because an item in its absolute singularity can only be specified asymptotically by locating it as the intersection or focus of an in principle endless conjunction of descriptions. ${ }^{104}$

\section{Universal, general and singular again}

It is now both possible and necessary to draw some conclusions as regards Althusser's considerations on laws and 'constants' and venture some independent remarks.

The first is that Althusser's general contrast in principle between, on the one hand, the domain of fixed types of things about which the natural sciences seek universal laws and the domain of 'cases', singular, unique, concrete, dealt with by, for instance, history and psychoanalysis, in terms of 'general' 'constants' is unacceptable, based on a premodern, 'Aristotelian' conception. All scientific knowledge starts with the singular and returns to the singular, via 'constants'. ${ }^{05}$

Now, we have seen in Section VIII that Althusser himself makes essentially this point, though in a way which renders it completely anomalous with regard to the general line of his argument. This is all the more peculiar when it is considered that he had said the same thing in the course of a critique of Lévi-Strauss as long ago as 1966:

... modern scientific thought sets out to think singularity, not only in history ... and psychoanalysis, but also in physics, chemistry, biology, and so on ... it is only possible to think the singular and concrete in concepts

104 Althusser's problem with grasping singularity in conceptual (universal, abstract) terms disappears when his general abstractionist theory of concept-formation is dropped. It may then be defined indirectly, for instance, as that which is the value of a variable (cf. Quine 1961, p. 13).

105 Cf. Freud, New Introductory Lectures on Psychoanalysis, lecture XXIX, Complete Psychological Works, S.E. 22: p. 29. 'If, for the sake of studying it, we isolate one particular psychical function, such as dreaming, from the psychical machinery as a whole, we make it possible to discover the laws that are peculiar to it; but when we insert it once more into the general context we must be prepared to discover that these findings are obscured or impaired by collision with other forces.' Althusser's contrast seems to be a rather peculiar resurrection of the distinction, which arose round the turn of the century between 'nomothetic'. and 'ideographic' disciplines, arising in the work of neo-Kantian philosophers like Windelband and Rickert, but active in the work of, for example, Weber. However, Althusser does not introduce the characterisation of the second in terms of values as occurs in this tendency. 
(which are thus 'abstract' and 'general'); but that is the very condition for thinking the singular, since there can be no thinking without concepts (which are, consequently, abstract and 'general'). ${ }^{106}$

It may be added that what has been said does not imply that relevant and indeed necessary distinctions between sciences cannot be drawn. The most apposite such distinction in the present context is probably that between the context in which what is sought and presented are 'constants' and the context in which what is sought and presented are explanations of singular cases and the construction of certain unique sequences of the latter, those 'narratives' which may be inclusively called 'histories', which, indeed, are in general the basis of explanations of singular cases. This distinction holds in the case both of natural and non-natural sciences. (For the case of the natural sciences, see the singular sequences sought by cosmology underpinned by physics, by geology - for example, concerning continental drift - by macrobiology regarding the evolution of species, and so on). ${ }^{107}$ It may be noted that the first volume of Capital is built throughout on the plan of an alternation of general theoretical chapters and historical ones based on the latter.

No distinction between the natural and 'non-natural' cases can be drawn on the basis of a distinction between the province of Geschichte and the rest; genuine novelties occur in both nature and human history, ${ }^{108}$ and in both 'constants' are sought.

The applicability or otherwise of experiment does not determine a difference in kind between the two domains either. Marx mentions in the preface to the first edition of the first volume of Capital the role of experiment in the natural sciences in producing 'pure cases', but assigns no special significance to this: he simply remarks that in economics the 'power of abstraction' must replace

106 Althusser 2003, p. 55.

107 Of course, there may be a distinction between what may be called the 'ranges' and what maybe called the 'levels' of applicability of those disciplines which are oriented to the universal or general. Thus, as regards 'range', the subject-matter of theoretical physics is commonly thought of (rightly or wrongly) as coextensive with the universe as a whole, and its theories as applying, to the extent that they do anywhere, everywhere, whilst the subject-matter of the sciences of life is almost certainly fairly restricted, spatio-temporally. As regards 'level', the various branches of theoretical physics tend to be specific, for instance, the 'classical' domain and the 'quantum' domain, and within the former, 'macroscopic' and 'microscopic' (e.g. phenomenological thermodynamics versus statistical mechanics). But these considerations do not touch the points made in the main text.

108 See Prigognine and Stengers 1984. 
it, that is, that what is abstracted in fact in natural science must, in political economy, be abstracted only in thought. No fundamental distinction can be drawn on the basis of the greater prevalence of experiment in the domain of the natural sciences. On the one hand, this is only true, at best, of the fundamental natural sciences (for example, cosmology in itself is not an experimental science - its experimental basis is in the physics involved), and, on the other, experiment is not excluded in principle from the non-natural sciences. ${ }^{109}$

\section{Aleatory materialism and/as philosophy}

The question of the character of aleatory materialism qua philosophy

Althusser wrote as far back as 1967 that Marx had introduced 'a ... new ... . practice of philosophy', ${ }^{110}$ that is, that he had not abandoned philosophy as such but rather introduced a new sort of philosophy. Along similar lines he wrote in 1976:

Marx did not discover a new philosophy ... but adopted a new philosophical standpoint, in a field (that of philosophy) which both pre-existed him and continued after his death.... [For Marx and Lenin] [i]t was no longer a question of creating a new philosophy in the classic mould, but of reworking the categories which had always existed in the history of philosophy and still did on this new basis. ${ }^{111}$

All this immediately suggests the question: how does aleatory materialism fit into this 'new practice of philosophy', this 'new philosophical standpoint'? In other words: if it is not a 'new philosophy', what is its character qua philosophy?

\section{Marx's 'new practice of philosophy' (I)}

Answering this question involves answering a prior question: What, more precisely, is the 'new practice of philosophy', the 'new philosophical standpoint' referred to? And answering this question in turn involves answering the

${ }_{109}$ On experiment in psychology, see Lewin 1927 and 1935. Lewin, in turn, was a central influence on the account of the relation between laws and individual cases in psychology presented in Holzkamp 1983, Chapter 9, especially pp. 545ff.

${ }_{110}$ Althusser 1971, p. 67.

111 'The Facts' in Althusser 1994e, pp. 359, 360. 
questions: what, according to Althusser, is philosophy in general? And, more specifically: what is the practice of this philosophy with respect to which the new practice of it is new?

Althusser offered answers to these questions in work contemporary with 'Lenin and Philosophy' and in particular in his contribution to the co-operative 'Cours de philosophie pour scientifiques' given at the École normale in 1967. The first four parts of this contribution were later published as (in the English version) Philosophy and the Spontaneous Philosophy of the Scientists. The fifth and final part, of special importance for the present theme, was unaccountably not included in this volume but is now available in Althusser 1995. These ideas were, in effect, restated and filled out in his later work, which also, beginning with Althusser 1990a [1976], contains new developments. This and the following subsection attempt a very brief synoptic statement of what in all this is primarily relevant to the present question.

What is constitutive of philosophy as such (as distinct from, in particular, 'world views') 112 is a special relation to the sciences, the way it treats the sciences in situating itself with respect to them. What is specific to a traditional philosophy is the dual character of this relation. On the one hand, it assigns the sciences a certain limited and subordinate place with respect to itself. On the other hand, it declares itself a science, in general on the alleged basis of a form of rationality deriving from an existing science, but a sort of superscience, the science of sciences, claiming to offer the Truth about the Whole of what there is, its Origin and End. This alleged Truth is, in the final analysis, a vehicle of dominant class-ideologies, and in particular political ideologies.

This Truth is thought of as being encapsulated in

logos, or origin, or meaning. And since there are common origins between logos and speech ... there is only one means of knowing logos, and hence Truth: the form of discourse. This intimacy between logos and speech means that truth, logos, can be entirely enclosed or captured and offered up only in the discourse of philosophy. For this reason... its discourse is not a medium, or an intermediary between it and truth, but the very presence of truth as logos. ${ }^{113}$

The key to overturning this traditional practice of philosophy and instituting the new - Marxist-materialist - practice of philosophy is briefly as follows:

112 On which see Althusser 1995, pp. 260-2, 289.

113 Althusser 1990a, p. 246 - cf. Althusser 1994d, p. 50. 
'materialist philosophies affirm the primacy of practice over theory'. ${ }^{114}$ There follows at this point a passage ${ }^{115}$ which, in effect, repeats in a much more elliptical way what Althusser had already set out in much more detail in his earlier Althusser 1990a. Let us therefore follow this more accessible because more explicit presentation.

In his first thesis on Feuerbach, Marx claims that all hitherto existing materialism conceives reality (etc.) in the 'form' of the 'object [Objekt]' or of 'contemplation [Anschauung]'. To this, Marx counterposes 'practice'. However, in doing so he

has not introduced any philosophical notion on a par with the 'object-form' and the 'contemplation-form', and hence destined to replace them in order to establish a new philosophy, to inaugurate a new philosophical discourse. Instead, he establishes a reality that possesses the particularity of being at one and the same time presupposed by all traditional philosophical discourses, yet naturally excluded from such discourses. ${ }^{116}$

What Althusser means here by saying that practice is 'presupposed' yet 'excluded' by all traditional philosophical discourses is elucidated as follows.

What in fact are the 'object-form' and the 'contemplation-form'? ... in the guise of the metaphor of vision (a metaphor interchangeable with the metaphor of presence or that of the speech of the logos), they are the very condemnation of the claim of any philosophy to maintain a relation of discursive presence with its object.... the peculiarity of the philosophical conception of the truth is its inability to exist in any other form than that of the object, or of contemplation. In both cases we confront the same privilege, the same claim. For philosophy men live and act subjected to the laws of their own social practices, they know not what they do. They believe they possess truths, they are not aware of what they know. Thank God philosophy is there, that it sees for them and speaks for them, tells them what they do and what they know. ${ }^{117}$

The passage continues:

\footnotetext{
114 Althusser 1994d, p. 60.

115 1994d, pp. 60-2.

116 Althusser 1990a, p. 248.

117 Ibid.
} 
... the irruption of practice is a denunciation of philosophy produced as this kind of 'philosophy'.... [I]t opposes philosophy's claim to embrace the ensemble of social practices (and ideas), to see the 'whole' ... in order to establish its dominion over these same practices. It is counter to philosophy that Marxism insist that philosophy ... exists only through and for ... [an] 'exterior'. This exterior (which philosophy wishes to imagine it submits to Truth) is practice, the social practices.... In contrast to the logos (that is, to a representation of something supreme, to what is called 'Truth', whose essence is reducible to 'speech' ....). Practice, which is utterly foreign to the $\log o s$, is not Truth and is irreducible to - does not realise itself in - speech or sight. Practice is a process of transformation which is always subject to its own conditions of existence and produces, not the Truth, but rather 'truths' (or the truth, let us say, of results or of knowledge, all within the field of its own conditions of existence). And if practice has agents, it nevertheless does not have a subject as the transcendental or ontological origin of its objective, its project, nor does it have a goal as the truth of its process. It is a process without subject or goal.

If we take the term Truth in its philosophical sense ... it must be affirmed that there is no truth of practice.

Accordingly, there is a problem involved in assigning practice the role of Truth, of foundation, of origin, in a new philosophy that would be a philosophy of praxis.... [P]ractice is not a substitute for Truth for the purposes of an immutable philosophy, on the contrary it is what knocks philosophy off balance.... [P]ractice is what philosophy ... has never been able to incorporate.... [P]ractice compels philosophy to recognise that it has an exterior. ${ }^{118}$

Thus, from this standpoint, there is a renunciation in principle of claims to knowledge of the Truth and this because it rests on a thesis of the primacy of practice about which there are no unconditional truths, practice giving rise only to partial conditioned truths. ${ }^{119}$ Spinoza, for one, escaped the temptation

118 Althusser 1990a, pp. 248f - see also Althusser 1994a, p. 254 and Althusser 1994d, p. 60 .

119 The idea of the primacy of practice gives a non-metaphysical/ontological basis for taking the world to be the totality of facts and not of things. For practices, in their cognitive aspect anyway, always begin and end (both of these to be understood contextually) with assertions that something is the case, even if this is presupposed by a question (problem) resting on assertions. 
of the Truth: '[he] speaks, clinically, of the "true", not of the Truth. He held that "the true is the index of itself and the index of the false". It is the index of itself not as presence but as product, in a double sense: 1) as the result of the labour of a process that discovers it, and 2) as proving itself [se prouvant] in its very production'. ${ }^{120}$

A genuinely materialist philosophy

does not pretend to be autonomous or to found [fonder] its own origin and its own power. Nor does it consider itself to be a science, and still less the Science of sciences. In this sense it is opposed to all positivism. In particular, it should be pointed out [signaler] that it renounces the idea that it possesses the Truth. ${ }^{121}$

This means, among other things, that 'the primacy of practice' must not be conceived of as asserting a new fundamental truth, as such an idea (represented by, for example, a 'philosophy of praxis') would represent a regression to the old idea of philosophy as a provider of foundations, guarantees.

All this opens up the possibility of 'a philosophy which remains philosophy, but ceases to exploit the sciences'. ${ }^{122}$ To remain philosophy, it must have a special relation to the sciences. But, if it does not exploit the sciences, then it cannot have an object, like the sciences, about which it furnishes alleged (privileged) knowledge, because all cognitive niches in the ecology of knowledge (with respect to claims about what is the case) are always already filled, or, at least, reserved, by some specific practice of scientific inquiry.

What fits this bill is the idea of philosophy not as a matter of making various assertions about the world, but of a certain activity, ${ }^{123}$ namely, that of drawing 'lines of demarcation' between what is scientific and what is ideological, taking up 'positions', 'theses' (to recall the etymologically original sense): between a materialist and an idealist approach, a contrast which coincides with the division in the class struggle between working class and bourgeoisie respectively. The lines may be drawn in theory, in which case

${ }_{120}$ Althusser 1994d, p. 59.

121 Althusser 1994d, p. 60.

122 Althusser 1995, p. 265.

${ }^{123}$ This is another similarity between Althusser and Wittgenstein, for the latter, in both his earlier and later thought, though in somewhat different ways in each, considered philosophy to be a certain sort of 'activity' rather than as an attempt to set up doctrines. Of course, there are fundamental differences between the two thinkers as regards the character of the activities envisaged. 
philosophy is ('in the last instance' - Althusser emphasises this qualification) ${ }^{124}$ a matter of representing working-class political interests, or in politics where it is a matter of defending working-class theoretical interests. ${ }^{125}$ An activity, a practice differs as regards its very categorial character from an assertion, which belongs to the domain of theory. The assessment appropriate to the latter is 'true' (or 'false'), that appropriate to the former is 'correct [juste]' (or 'incorrect'). ${ }^{126}$ Thus, materialism as a philosophical position cannot properly be said to affirm something about the world as a Whole, or even, as was noted above, about the primacy of practice. ${ }^{127}$ So, philosophy conceived in this way is connected in a dual way with practice: firstly, it is itself a practice, and, secondly, this practice is a matter, inter alia, of representing the standpoint of the primacy of practice.

There are (contextually determinate) procedures for checking the truthvalue of assertions. How are claims of 'correctness' associated with a 'position' or 'thesis' to be assessed? It cannot be in terms of grounds which are logically and epistemically prior to it, since the materialist position as such rejects any such a priori grounds. So, if it cannot be judged in terms of grounds - 'causes' in an older usage of the word - it can only be in terms of its effects. ${ }^{128}$

... a good materialist should ... judge a philosophy ... by its acts, its mode of action, which is not just any mode of action, but the specific mode by

${ }^{124}$ For example, Althusser 1994d, pp. 55f.

125 Althusser states clearly in Althusser 1994e (p. 169) that he still held to the first of these definitions, though he does not disclaim the second (he simply does not mention it). Cf. also Althusser 1994d, pp. 5, 35, 127.

126 See, for example, Althusser 1994d, p. 79n.

${ }^{127}$ Is this a possible example of the procedure alluded to in an enigmatic remark from 1976: 'the nub of all philosophical (as well as political and military) problems ... [is] ... how to escape the circle while remaining within it' (Althusser 1994e, p. 319)?

128 The determination of these effects is not itself a business of philosophy as such. 'The philosopher ... has no tools or procedures for verifying things. He must limit himself to putting forward theses without ever being able to verify them himself. He must always anticipate the effects of his philosophical claims without even knowing when or how they will manifest themselves. Obviously, he does not put forward positions arbitrarily but takes into account what he perceives to be the Whole, or believes it to be, and the way it is evolving, and sets them against existing arguments in his own field.' (Althusser 1994e, pp. 172f). In the title piece in 1990, he writes in Althusser 1994e, p. 174, he expressed the view that 'all philosophy was essentially dogmatic.... It put forward its claims as true and was concerned solely with putting them forward.' In Althusser 1997, at p. 4, Althusser speaks of 'the truth of a philosophy' but this is clearly only a manner of speaking. As he goes on to speak in familiar terms, saying that this truth 'lies entirely in its effects, while in fact it acts only at a distance from real objects, therefore, in the space of freedom that it opens up to research and action...' (The whole passage at this point repays careful study.) 
which a philosophy acts: by which it acts on ideologies, and, by way of those ideologies, on practices.... [L]imit-cases aside, a philosophy never acts directly on practices, but, almost always, acts by way of ideologies. This is what one might call, in order to bring out its specificity, the 'philosophyeffect'. It follows that in order to be able to characterize a philosophy ... it is necessary to consider it in its effects on practices: does it exploit them or does it respect and assist them, etc.... The closer a philosophy comes to the practices, the more it respects them, the more it assists them by way of ideologies, the more a philosophy tends towards materialism, a materialism other than that inscribed in the pair idealism/materialism, which is a speculary pair. ${ }^{129}$

What this signifies is well illustrated in Althusser's 'Reply to John Lewis' (1972). He argues here that Lewis's positions have two sorts of deleterious effects. One is political:

if the workers are told that 'it is men who make history' ... sooner or later, that helps to disorient or disarm them. It tends to make them think that they are all-powerful as men ... prevents them from making use of the only power they possess: that of their organizations as a class and their class organizations... by which they wage their class struggle. ${ }^{130}$

This is clearly philosophy at work in the domain of politics, representing the standpoint of materialist theory there.

The second deleterious effect of Lewis's positions is that they " prevent" the development of existing scientific knowledge... are an obstacle to the development of knowledge. Instead of helping it to progress, they hold it back ...' ${ }^{131}$ Althusser goes on:

That is how philosophy 'works' in the sciences. Either it helps them to produce new scientific knowledge, or it tries to wipe out these advances and drag humanity back to a time when the sciences did not exist. Philosophy therefore works in the sciences in a progressive or retrogressive way. Strictly speaking, we should say that it tends to act in one way or another - for every philosophy is always contradictory. ${ }^{132}$

\footnotetext{
${ }^{129}$ Althusser 1994d, pp. $101 \mathrm{f}$.

130 Althusser 1976, pp. 63f.

131 Althusser 1976, p. 60.

132 Althusser 1976, p. 61.
} 
This is, then, philosophy at work in the sciences. But, so far, there is no mention of working-class interests, only of purely cognitive ones. However, he goes on to say that a certain idealist thesis presented by Lewis 'paralyzes revolutionary philosophers, theoreticians and militants. It disarms them, because in effect it deprives them of an irreplaceable weapon: the effective knowledge of the conditions, mechanisms and forms of the class struggle' ${ }^{133}$ That is, working-class interests are represented in theory indirectly, via cognitive interests. The not entirely explicit premise here is that the advancement of knowledge is in working-class interests. The argument would appear to be not that claims to knowledge are justified because they are in working-class interests, but rather, conversely, justified claims to knowledge are in workingclass interests.

With respect, then, to the domain of theory in particular, the gist of what has been said may be put in an only slightly different way by saying that a materialist line/position is justified, in the first instance, to the extent that it keeps particular practices of production of knowledge epistemically 'open', preventing premature (ideologically based) 'closures' which work to prevent the posing of new problems and solutions to them. ${ }^{134}$ This, in turn, is justified,

133 Ibid.

134 This way of putting the matter brings Althusser's conception into close connection with one of Engels's characterisations of materialism as the idea of conceiving 'the real world - nature and history - just as it presents itself to anyone who approaches it without preconceived idealist fancies [Schrullen] ... to sacrifice mercilessly every idealist fancy which could not be brought into harmony with the facts conceived in their own and not in a purely imaginary [phantastischen] interconnection. And materialism as such means nothing more than this' (Althusser 1970, p. 361). In fact, Althusser sometimes alludes to this passage (e.g. Althusser 1971, pp. 43, 59; Althusser 1976, p. 194, n. 19; Althusser 1997, p. 6). See also Althusser's remarks in Althusser 1994e: "Not to indulge in storytelling" still remains for me the one and only definition of materialism' (p. 121) and 'my objective never to tell myself stories, which is the only "definition" of materialism I have ever subscribed to' (p. 169). Further, pp. 211, 223, and cf. Althusser 1994f, p. 523. It is also true that Althusser has, on at least one occasion, formulated the materialist conception in the sort of 'metaphysical' way fairly standard in the later Marx and in Engels: 'Philosophy of a materialist tendency recognizes the existence of objective external reality, as well as its independence of the subject who perceives or knows this reality. It recognizes that being, the real, exists and is anterior to the discovery of it, to the fact of being thought or known' (Althusser 1994d, p. 60). There is no room here for a criticism of this way of putting the matter. I have argued in Suchting 1986, Study 2, that arguments for 'philosophical' materialism considered as a true or false doctrine are basically dogmatic or what in fact comes to the same thing circular (question-begging): they all basically, at some point, simply affirm or presuppose what is supposed to be being proved. It may be noted here, as regards the Engels formulation, that it is not inconsistent with scientists actually holding non-materialist views. This was particularly in question in Lenin's Materialism and Empirio-Criticism, 
it would seem, by reference to the claim that the cause of the emancipation of the working class is forwarded by the growth of knowledge. How is this claim justified? Presumably by the ascertainable effects of the latter on the former.

\section{Marx's 'new practice of philosophy' (II)}

Beginning with Althusser 1990a, Althusser began a new development in his theory of philosophy. It is expressed in a very lapidary form in the following passage written in 1984:

My main idea [idée maîtresse] can be summed up in a few words: philosophy is, as it were, the theoretical laboratory, solitary and isolated, despite all the links tying it to the world, in which are elaborated categories appropriate for [propres à] thinking, and, above all, for unifying/diversifying, appropriate for thinking the various existing ideologies in unitary/unifying forms... there is an ... exigency to unify diverse (and contradictory) ideologies in order to draw them into the process of the constitution (never completed, infinite, see Kant's regulative idea) of what can be called the dominant ideology. 135

It had already been put in Althusser 1990a as follows:

... philosophy produces theoretical schemas, theoretical figures that serve as mediators for surmounting contradictions and as links for reconnecting the different elements of ideology. Moreover, it guarantees (by dominating the social practices thus reordered) the Truth of this order, enunciated in the form of the guarantee of a rational discourse. ${ }^{136}$

especially in the chapter on 'The Crisis in Physics': a distinction is made between the scientist's actual work and his philosophical views about his work. This work of Lenin's also contains, besides the usual 'metaphysical' conception of materialism (certainly the main one), other elements which seem at least compatible with the 'lines' conception, for instance his distinction between matter as (scientific) 'concept' and (philosophical) 'category', his criticism of Mach in terms of the effects of his philosophical questions (closing off questions), and his account of dogmatism/scepticism (for references see Suchting 1986). Althusser refers to matter as a 'category' in Althusser 1971 , p. 50. See also Lecourt 1973. (Further queries belonging to this general area arise with a consideration of the question of the status of the idea of a 'Marxist philosophy' in general. See note 52 above.)

${ }_{135}$ Private letter published in Althusser 1994d, pp. 114, 115, cf. Althusser 1994d, pp. 49f, 66, 76-9, Althusser 1994e, p. 359f. At Althusser 1994d, p. 66, he remarks that this role was originally played by religion. See also Althusser 1994e, p. 359 (cf. Dewey 1938).

${ }_{136}$ Althusser 1990a, p. 259. 
Althusser then poses the following question:

... if, in the last instance, philosophy plays the role of laboratory for the theoretical unification and foundation of the dominant ideology, what is the role of philosophers who refuse to serve the dominant ideology? ... Put another way: if what I have proposed is plausible, how is a Marxist philosophy conceivable? ${ }^{137}$

The second formulation of the question registers the at least prima facie inconsequence of the first formulation: if philosophy is at least partly constituted in terms of its function in helping to form a dominant ideology, it would seem that there logically cannot be something properly termed a 'philosophy' which does not have this function. Caedit quaestio.

Althusser begins his answer as follows:

In order to grasp its possibility, it is sufficient to reflect on the fact that the expression 'dominant ideology' has no meaning if it is not set against another expression: the dominated ideology.... The fact that, in a society divided into classes, the dominant class must forge an ideology that is dominant ... issues in a process that unfolds with a good deal of resistance. Particularly because ... there exist in class society what Lenin called 'elements' of another distinct ideology, that of the exploited class. The ideology of the dominant class does not constitute itself as dominant except over and against the ideological elements of the dominated class.

\section{He continues:}

A similar opposition can be found within philosophy itself. ... Philosophy, which works in its own theoretical laboratory to the benefit of the ideological hegemony of the ascendant or dominant class, without realizing it, confronts its own adversaries, generally under the name of materialism.... The forms of philosophical partisanship for the dominated class are represented in the forms that constitute philosophy, and hence under the forms of the question of ideological hegemony. Thus it is that the entire history of philosophy resounds deafeningly with the echo of the exploited or the opponents. Some, such as the eighteenth-century materialists, went so far as to oppose their own system of truth to the representatives of the dominant class. But rather 
than the eighteenth-century materialists ... perhaps those who ought to interest us are the ones who only half succeeded (or hardly succeeded) in imparting to their opposition the form of a philosophy produced as 'philosophy'. For my part I would closely investigate the cases of Epicurus and Machiavelli, to cite only them. But if I do so, it is only to try to understand Marx... ${ }^{138}$

Thus, we have the sudden introduction of a distinction between 'philosophy' and " philosophy"'. The use of this terminological couple renders many passages devoted to the present theme very confusing. The situation seems to be as follows. What Althusser characterises in the passage we started with as philosophy tout court (that is, roughly, the unifying discourse of the dominant ideology which is, in the first place, the ideology of the dominant classes) comes to be called 'philosophy', which is in fact only one form of what is actually philosophy tout court. The dominated classes in general also represent themselves philosophically in the forms of the dominant ideology, that is, as 'philosophy'. The question then becomes: how can dominated classes represent themselves philosophically in a form independent of the forms of the dominant ideology, that is, not as 'philosophy', but as an alternative form of philosophy as such? In particular, it is a question of how this is possible with respect to the working class, and, since Marxism is the standpoint of the latter, how there can be a Marxist philosophy, rather than a Marxist 'philosophy'. This elucidation permits a clearer reading of the passages quoted so far and should do the same for ones about to the quoted in resuming the thread of the exposition.

Althusser writes: 'When we observe the history of the Marxist workers' movement through the prism of the philosophical forms in which it has recognised itself, we encounter two typical situations.'

In the first we find ourselves with Marx, Engels, Lenin, Gramsci and Mao, who, in one way or another, always give the impression of distrusting like the plague anything that might appear to be a philosophy produced as ... 'philosophy', in the forms of ideological hegemony we have analyzed.

By contrast, we find ourselves in the second situation with people like Lukács ... and above all with Stalin... who was ... decisive in opening the highway for a Marxist philosophy produced as 'philosophy' ... 
... it is as if ... Marx, Lenin and Gramsci had suggested that the philosophy required by Marxism was by no means a philosophy produced as 'philosophy', but rather a new practice of philosophy. .. . Marx has bequeathed Marxists ... the task of inventing new forms of philosophical intervention to hasten the end of bourgeois ideological hegemony. In sum: the task of inventing a new practice of philosophy. ... This new practice of philosophy serves the proletarian class struggle without imposing upon it an oppressive ideological unity ... but rather creating for it the ideological conditions for the liberation and free development of social practices. ${ }^{139}$

Read in the way suggested, this joins seamlessly onto the account of the 'new practice of philosophy' outlined above. Synoptically, Althusser's account is briefly as follows. Philosophy as such, as a genus, is constituted by a special relation to science involving in the most general way the interests, expressed in ideologies, of groups engaged in social, and in particular class, conflict. Traditional philosophy ('philosophy') proceeds by exploiting the sciences and giving dominant interests/ideologies a fictitious unity in the form of claims about the Truth regarding the Whole. The 'new practice' of specifically Marxist philosophy combats ideological exploitation of the sciences because (ultimately) it is contrary to working-class interests, but also combats any attempt to impose on the working class 'an oppressive ideological unity'.

\section{The character of aleatory materialism qua philosophy}

It is now possible to sketch an answer to the question posed earlier ('the question of the character of aleatory materialism').

At first sight, the answer may seem to be somewhat as follows. The special character of aleatory materialism qua philosophy is that it rejects all the various claims of traditional philosophy to ground the totality of what there is in some all-embracing principle, transcendent or immanent, which accounts for how it is (Origin) and where it is heading (End) and to replace this with a theory of universal, radical contingency. Such a view of the matter might well call on passages like the following.

For Epicurus and aleatory materialism, Althusser writes,

139 Althusser 1990a, pp. 262, 264, 265. At certain points, Althusser seems to want to say that if there is no 'philosophy or physics, mathematics etc., then, insofar as Marx's achievement was mainly scientific, there is no "philosophy of Marxism" as distinct from a "philosophy for" Marx(ism)'. See Althusser 1994d, pp. 23, 35f, 37f, 39, 87-9. 
... before the formation of the world, there was no Meaning [Sens], neither Cause nor End nor Reason nor Unreason [Déraison].... All question of Origin is rejected, as are all the great philosophical questions: 'Why is there something rather than nothing? What is the origin of the world? What is the world's raison d'être? What is man's place in the ends of the world?' and so on.... [For there to be] a structure of Being or of the world that assigns each of its elements its place, meaning, and role, or, better, establishes ... the atoms as elements of bodies, of beings, of the world ... it is necessary that the world exist, and, prior to that, that the atoms exist [il faut que le monde soit, et les atomes déjà], a situation which puts... the philosophy of Being for ever in second place ... thus making ... impossible ... any discourse of first philosophy. ${ }^{140}$

This obviously rules out Plato and Aristotle, for instance. But it also 'explains why Epicurus ... never subscribed to the "mechanical" materialism of Democritus, this materialism being only a resurgence, within a possible philosophy of the encounter, of the dominant idealism of Order as immanent in Disorder)'. ${ }^{141}$ This bespeaks Epicurus's 'audacity': what other philosophy has ever put forward 'the thesis that Swerve was originary [originaire], not derived $?^{\prime 142}$

What then, on the basis of this thesis, does philosophy come to?

... philosophy is ... [the] theory of their contingency and a recognition of fact, of the fact of contingency, the fact of the subordination of necessity to contingency, and the fact of the forms which 'gives form' to the effect of the encounter. It is now no more than observation [constat]: there has been an encounter, and a 'taking-hold' [prise] of the elements with one another. ${ }^{143}$

The central problem with the answer sketched to start with, and supported by at least one reading of passages of the kind just quoted, is that it runs the risk of representing aleatory materialism as basically just another traditional philosophy, in particular, another form of materialism. In this way, the denial that the Whole has any Origin or End as its Truth is itself really about the Whole, is a different answer to questions posed within the traditional practice, a heretical answer, so to speak, but not an answer different in principle to

\footnotetext{
${ }_{140}$ Althusser 1994b, pp. 541, 542, 565.

141 Althusser 1994b, p. 565.

142 Althusser 1994b, p. 541.

143 Althusser 1994b, p. 542.
} 
traditional ones - something in the way in which a diabolism is a form of theism. On this reading, it may be taken to be something like a version of indeterminism, either of a more or less purely speculative sort, like Peirce's 'tychism', ${ }^{144}$ or with putative scientific backing, like Popper's, ${ }^{145}$ opposed, most clearly, to a general determinism.

Quite independently of what has been said above, an indication that this is an 'incorrect' answer is provided by Althusser's reluctance, expressed here and there, to call aleatory materialism a 'materialism' at all.

As we saw to start with, Althusser claims that all traditional philosophies (presumably, he means at least all 'superterranean' traditional philosophies) are, tendentially, either idealisms or materialisms - 'tendentially' because, not only idealism but also the historically most visible and influential forms of materialism, bear traces of their opposites within themselves.

In the interviews published in Althusser 1994d, Althusser's interlocutor asks at one point: 'Have any philosophies escaped the idealism-materialism pair?'. ${ }^{146}$ He replies:

... if certain philosophies escape this pair, they can be recognized by the fact that they escape, or attempt to escape, questions of origin and end, that is, ultimately, the question of the End or Ends of the world and of human history. These philosophies ... in avoiding the trap ... express the need to abandon idealism and move towards what may be called (if you like) materialism, thus distinguishing themselves, I repeat, from every philosophy of Origin - whether it is a matter of Being, the Subject, Meaning or Telos since it considers that these themes fall to religion and morality [la morale], but not to philosophy. ${ }^{147}$

Elsewhere, he writes (in effect apropos the parenthetical 'if you like' in this passage):

... are Epicurus's theses still materialist? Yes ... but on condition that we have done with a conception of materialism which, setting out from the questions and concepts it shares with idealism, makes materialism the answer to it. We continue to speak of a materialism of the encounter only for the

144 For example, Pierce 1992.

145 Popper 1982.

146 Althusser 1994d, p. 58.

147 Althusser 1994d, p. 58f. 
sake of convenience: it should be kept in mind that this materialism of the encounter eludes the classical criteria of every materialism, and that we need, after all, some word to designate the thing. ${ }^{148}$

But the only secure way of avoiding misinterpretations of aleatory materialism as a form of traditional materialism is not in the direction of terminological reform but in that of sticking to the letter of Althusser's doctrine about the character of philosophy as a practice of intervention, involving not assertions but 'positions', 'theses'. ${ }^{149}$ Specifically, aleatory materialism is a philosophical 'thesis' directed at combating 'closures', at enjoining optimal 'openness'. With respect to the cognitive-theoretical domain, this intervention is directed against both dogmatic and sceptical assumptions about what is or must be the case about the world. In particular, it should be understood as affirming anti-necessitarianism, not ontologically but in purely methodological terms. With respect to the practical-political domain, its intervention is directed at untested - even untestable - assumptions about the possibilities for emancipation, assumptions either about what forwards or what constrains it. As such, aleatory materialism may be compared with 'the principle of causality/determinism', interpreted not as an all-embracing assertion about how the world is (for example, 'Every event has a cause') but as a rule of procedure enjoining the search for certain sorts of conditions for what happens rather than others (such as teleological ones).

\section{Conclusion - further questions}

The preceding considerations have raised at various points, explicitly, or by implication, a number of lines of necessary further work.

First of all, there is an historiographical question, namely, that of the degree of fidelity of Althusser's presentation of the history of materialism to the relevant facts (however this expression might be construed). Even were this presentation to be found wanting to one or another extent, this would leave open, of course, the systematic - that is, general theoretical - value of Althusser's conception of aleatory materialism.

${ }_{148}$ Althusser 1994 b, p. 543 - see also p. 562. In a footnote to this last reference he refers to Lecourt's term 'surmatérialisme' and recommends his discussion of it in Lecourt 1981, Chapter 4.

${ }_{149}$ In this regard, it is important to note that Althusser regards Machiavelli's general principles about the course of history not as substantive scientific assertions but as philosophical 'theses' (Althusser 1995, pp. 79, 91). 
This last context involves a number of questions which stem from Althusser's own criterion for assessing a philosophical position (that is, the context of an immanent assessment), namely, that concerning both the cognitive and the political effects induced, or tending to be induced, by it.

The cognitive effects may be considered from two general points of view, (a) one is that of the advantages or otherwise of this approach for resolving - or, more precisely, dissolving - traditional (including, of course, current) philosophical problems. For instance, aleatory materialism has a crucial bearing on the seemingly endless disputes about modalities, particularly with reference to the question of the character of 'laws of nature'. ${ }^{150}(\mathrm{~b})$ The other perspective is that from the sciences. From this angle, questions concern (i) the consonance or otherwise of aleatory materialism with already well-established results of the sciences and, in particular, the contemporary sciences. Possible areas of inquiry here include the treatments of that area of non-linear processes in physics popularly known as the domain of 'chaos theory' and work in biology both molecular and macro-evolutionary. ${ }^{151}$ The questions concern (ii) an assessment of the effects which an aleatory materialism might foreseeably have in the sciences, which would include a consideration of the possible deleterious effects which non-aleatory materialism may have induced. An area of special interest to those engaged in the Marxist tradition is, for instance, interpretations of historical materialism in terms of evolutionary 'progress', often rooted in theories of pan-historical technological progress. ${ }^{152}$

The political effects may be studied from the point of view of the historical effects of non-aleatory materialism on emancipatory movements and from the point of view of its potential effects. Again, the history of Marxist theory and its actual and potential political effects must be a prime point of interest.

150 The contemporary state of this discussion may be studied very conveniently and comprehensively in Weinert 1995.

${ }_{151}$ 'Chaos theory' is more exactly defined by Kellert in his excellent book on the subject as the field of 'the qualitative study of unstable periodic behaviour in deterministic nonlinear dynamical systems' (Kellert 1993, p. 2). On the subject see also Kamminga 1990. On geology, see Davis 1996, and in biology see, for example, Gould 1989, especially Chapter 5, Jacob 1982, Monod 1977, Pollack 1994 (especially Chapter 3). Dupré 1993 contains much of relevant interest.

152 See Althusser's critique of Marx on capitalism as a mode of production in Althusser 1994b, pp. 570-6 and, more generally, his book, posthumously published in Althusser 1994c, Marx dans ses limites (1978). See, also Suchting 1993, 1994, Wallerstein 1995 , p. 8 , notes 'the enormous subterranean strength of the faith in inevitable progress' and contributes a powerful critique of the idea, especially in the Marxist tradition (pp. 97ff). 
For instance, the standpoint of aleatory materialism is fairly clearly inconsistent with the view, rooted deeply in Marx's own work from beginning to end (stemming, arguably, from Hegel) that political aims, strategic and also tactical, as well as political means to those ends, are basically a matter of the realisation, the making 'for itself' of what is already present 'in itself' in the socialhistorical situation.

\section{References}

Alexandrov, Aleksandr D., et al. (eds.) 1963, Mathematics, Volume 1, Cambridge, MA.: MIT Press.

Althusser, Louis 1971, Lenin and Philosophy and Other Essays, London: NLB.

Althusser, Louis 1976, Essays in Self-Criticism, London: NLB.

Althusser, Louis 1988a, Filosofia y marxismo, Mexico City: Siglo XXI.

Althusser, Louis 1990, Philosophy and the Spontaneous Philosophy of the Scientists and Other Essays, edited by Gregory Elliott, London: Verso.

Althusser, Louis 1990a [1976], 'The Transformation of Philosophy', in Althusser 1990.

Althusser, Louis 1993, 'L'unique tradition matérialiste (1985)', Lignes, 18: 75-119. (Also in Althusser 1994e; partially translated in Althusser 1997.)

Althusser, Louis 1994a, 'Note sur les Thèses sur Feuerbach', Magazine littéraire, 324, September: $38-42$.

Althusser, Louis 1994b, 'Le courant souterrain du matérialisme de la rencontre', in Althusser 1994d.

Althusser, Louis 1994c, Écrits philosophiques et politiques, Volume I, Paris: Éditions Stock/IMEC.

Althusser, Louis 1994d, Sur la philosophie, Paris: Gallimard.

Althusser, Louis 1994e, The Future Lasts a Long Time and the Facts, London: Vintage.

Althusser, Louis 1994f, L'avenir dure longtemps, suivi de Les Faits, new edition, enlarged, Paris: Éditions Stock/IMEC.

Althusser, Louis 1995, Écrits philosophiques et politiques, Volume II, Paris: Éditions Stock/IMEC.

Althusser, Louis 1997, 'The Only Materialist Tradition', in The New Spinoza, edited Warren Montag \& Ted Stolze, Minneapolis: University of Minnesota Press.

Althusser, Louis 1999, Machiavelliand Us, translated by Gregory Elliott, London: Verso.

Althusser, Louis 2003, The Humanist Controversy and Other Writings, translated by G.M. Goshgarian, London: Verso.

Balashov, Y.V. 1992, 'On the Evolution of Natural Laws', British Journal of the Philosophy of Science, 43: 343-71.

Black, Max 1964, A Companion to Wittgenstein's 'Tractatus', Ithaca: Cornell University Press. Burkamp, Wilhelm 1927, Begriff und Bezeihung, Hamburg: F. Meiner. 
Callari, Antonio \& David F. Ruccio (eds.) 1996, Postmodern Materialism and the Future of Marxist Theory. Essays in the Althusserian Tradition, Hanover: Wesleyan University Press.

Cassirer, Ernst 1922, Das Erkenntnisproblem in der Philosophie und Wissenschaft der neueren Zeit, 2 vols., Third Edition, Berlin: B. Cassirer.

Cassirer, Ernst 1953 [1910, 1921], Substance and Function and Einstein's Theory of Relativity, New York: Dover.

Cassirer, Ernst 1928, 'Zur Theorie des Begriffs', Kant-Studien, 31: 129-36.

Cassirer Ernst 1959 [1929], Philosophy of Symbolic Forms, Volume 3, Cambridge, MA.: Yale University Press.

Davis, Mike 1996, 'Cosmic Dancers on History's Stage? The Permanent Revolution in the Earth Sciences', New Left Review, I, 217, May-June: 48-84.

Dewey, John 1929, The Quest for Certainty, New York: Minton, Balch.

Dewey, John 1938, Logic, the Theory of Inquiry, New York: Holt, Rinehart, and Winston.

Dewey, John 1948 [1920], Reconstruction in Philosophy, Second Edition, Boston: Beacon Press.

Dilthey, Wilhelm 1960 [1911], Die Typen der Weltanschauung und ihre Ausbildung in den metaphysischen Systemen, in Gesammelte Schriften, Volume 8, Stuttgart: B.G. Teubner/ Göttingen: Vandenhoeck \& Ruprecht.

Dupré, John 1993, The Disorder of Things. Metaphysical Foundations of the Disorder of Science, Cambridge, MA.: Harvard University Press.

Engels, Friedrich 1970 [1884], Ludwig Feuerbach and the End of Classical German Philosophy, in Marx and Engels, Selected Works in Three Volumes, Volume 3, Moscow: Progress Publishers.

Epicurus 1994, The Epicurus Reader, Indianapolis/Cambridge, MA.: Hackett.

Fowler, Barbara H. (ed) 1992, Archaic Greek Poetry. An Anthology, Madison: University of Wisconsin Press.

Giere, Ronald N. 1988, Explaining Science, Chicago: University of Chicago Press.

Giere, Ronald N. 1994, 'The Cognitive Structure of Scientific Theories', Philosophy of Science, 61: 276-96.

Gould, Stephen J. 1989, Wonderful Life. The Burgess Shale and the Nature of History, New York: W.W. Norton.

Holzkamp, Karl 1983, Grundlegung der Psychologie, Frankfurt: Campus Verlag.

Jacob, François 1982, The Possible and the Actual, Seattle: University of Washington Press.

Jaspers, Karl 1994 [1919], Psychologie der Weltanschauungen, Munich: Piper.

Kamminga, H. 1990, 'What Is this Thing Called Chaos?', New Left Review, I, 181, May-June: 49-59.

Kellert, Stephen H. 1993, In the Wake of Chaos. Unpredictable Order in Dynamical Systems, Chicago: University of Chicago Press.

Lecourt, Dominique 1973, Une crise et son enjeu, Paris: Maspero.

Lecourt, Dominique 1981, L'Ordre et les jeux, Paris: Grasset.

Lenin, Vladimir I. 1962 [1908], Materialism and Empirio-Criticism, in Collected Works, Volume 14, Moscow: Foreign Languages Publishing House. 
Lewin, Kurt 1927, Gesetz und Experiment in der Psychologie, Berlin-Schlachtensee: Weltkreis Verlag.

Lewin, Kurt 1935, 'The Conflict between Aristotelian and Galilean Modes of Thought in Contemporary Psychology', in A Dynamic Theory of Personality, New York: McGrawHill.

Long, Anthony A. \& David N. Sedley 1987, The Hellenistic Philosophers, 2 volumes, Cambridge: Cambridge University Press.

Lucretius 1992, De rerum natura, Loeb Classical Library, Cambridge, MA.: Harvard University Press.

Macherey, Pierre 1976, 'L'Histoire de la philosophie considérée comme une lutte de tendences', La Pensée, 185, February.

Marx, Karl 1975 [1841], Difference Between the Democritean and Epicurean Philosophy of Nature/Notebooks on Epicurean Philosophy, in Marx and Engels, Collected Works, Volume 1, London: Lawrence and Wishart.

Marx. Karl and Friedrich Engels 1954-, Werke, Berlin: Dietz Verlag.

Monod, Jacques 1977, Chance and Necessity, London: Collins/Fount.

Nowak, Leszek 1980, The Structure of Idealization, Dordrecht: D. Reidel.

Peirce. Charles S. 1992 [1837-88], 'A Guess at the Riddle', in The Essential Peirce, Volume 1, edited by N. Houser \& C. Kloesel, Bloomington: University of Indiana Press.

Pirandello, Luigi 1987, Short Stories, translated by F. May, London/New York: Quartet Books.

Poincaré, Henri 1963 [1913], 'The Evolution of Laws', in Mathematics and Science: Last Essays, New York: Dover.

Pollack, Robert 1994, Signs of Life. The Language and Meanings of DNA, London: Penguin Books.

Popper, Karl R. 1982, The Open Universe, Totowa: Rowman and Littlefield.

Prigogine, Ilya \& Isabelle Stengers 1984, Order out of Chaos, London: Collins.

Quine, Willard van O. 1961 [1948], 'On What There Is', in From a Logical Point of View, Second Edition, New York: Harper \& Row.

Raymond, Pierre 1973, Le passage au matérialisme, Paris: Maspero.

Suchting, Wal 1986, Marx and Philosophy, London: Macmillan.

Suchting, Wal 1993, 'Reconstructing Marxism', Science E Society, 57: 133-59.

Suchting, Wal 1994, 'Reconstructing Marxism. Some Comments on Comments', Science $\mathcal{E}$ Society, 58: 325-31.

Suppe, Frederick 1989, The Semantic Conception of Theories and Scientific Realism, Urbana: University of Illinois Press.

Szymborska, Wislawa 1995, View With a Grain of Sand. Selected Poems, translated by Stanislaw Baranczak and Clare Cavanagh, New York: Harcourt Brace \& Co.

Wallerstein, Immanuel 1995, Historical Capitalism, with Capitalist Civilization, London: Verso.

Weber, Max 1949 [1904], "“Objectivity' in Social Science and Social Policy', in The Methodology of the Social Sciences, New York: Free Press.

Weinert, Friedel (ed) 1995, Laws of Nature: Essays on the Philosophical, Scientific and Historical Dimensions, Berlin: W. de Gruyter. 